\title{
Leguminosae no Parque Ecológico Paulo Gorski, Cascavel, Paraná, Brasil ${ }^{1}$
}

Leguminosae in the Parque Ecológico Paulo Gorski, Cascavel, Paraná, Brazil

\author{
Cristiane Snak ${ }^{2,5}$, Lívia Godinho Temponi ${ }^{3}$ \& Flávia Cristina Pinto Garcia ${ }^{4}$
}

\begin{abstract}
Resumo
Este estudo apresenta um levantamento florístico da família Leguminosae no Parque Ecológico Paulo Gorski, uma reserva natural no oeste do estado do Paraná, sul do Brasil e teve como objetivo contribuir para o conhecimento da flora de leguminosas no estado. As coletas ocorreram mensalmente, entre outubro/2007 e dezembro/2008, ao longo de trilhas preexistentes. Leguminosae foi representada por 29 espécies, alocadas em 26 gêneros. Senna foi o gênero mais representativo, com três espécies, seguido por Desmodium, com duas espécies. Os demais gêneros foram representados por uma única espécie. Este trabalho inclui chave de identificação, descrições, comentários, distribuição geográfica, fenologia e ilustrações das espécies.

Palavras-chave: Leguminosas, Fabaceae, florística, oeste do Paraná.
\end{abstract}

\begin{abstract}
This study presents a floristic survey of the Leguminosae family in the Parque Ecológico Paulo Gorski, a natural reserve in the western of the state of Paraná, south of Brazil and aimed to contribute to the improvement of the knowledge of the Legumes Flora in that state. Field collections were undertaken between October/2007 and December/2008, along the main trails. We found that Leguminosae was represented by 29 species in 26 genera. Senna was the most representative genus, comprising three species, followed by Desmodium, with two species. The other genera were represented by a single species. This work includes identification key, descriptions, comments, geographic distribution, phenology and illustrations of the species.
\end{abstract}

Key words: Legumes, Fabaceae, floristic survey, western Paraná.

\section{Introdução}

Leguminosae Juss. é a terceira maior família dentre as Angiospermas, compreendendo 730 gêneros e cerca de 19.400 espécies (Lewis et al. 2005). No Brasil, encontram-se cerca de 2.700 espécies reunidas em 212 gêneros (Lima et al. 2012a). As leguminosas são cosmopolitas, estando ausentes apenas na Antártida e encontram-se amplamente distribuídas nas regiões tropicais, tendo uma diminuição no seu centro de diversidade de acordo com o afastamento da linha do equador (Lewis 1987; Lewis et al. 2005).

Tradicionalmente, Leguminosae é subdividida em três subfamílias: Caesalpinioideae,
Mimosoideae e Papilionoideae (Lewis et al. 2005). Entretanto, estudos filogenéticos têm confirmado o monofiletismo de Leguminosae e de Papilionoideae, enquanto Mimosoideae é sustentada como monofilética apenas com a exclusão de Dinizia Ducke e Caesalpinioideae aparece como parafilética em todos os estudos de filogenia da família, sendo o grupo mais basal (Chappill et al. 1995; Wojciechowski et al. 2004; Bruneau et al. 2008).

As espécies da família são caracterizadas por apresentarem diversas formas de vida, geralmente com folhas alternas, compostas ou recompostas, com pulvino. A inflorescência é frequentemente

\footnotetext{
${ }^{1}$ Parte da monografia de conclusão de curso da primeira autora. Bolsista do Programa Institucional de Bolsas de Iniciação Científica.

${ }^{2}$ Universidade Estadual do Oeste do Paraná, Centro de Ciências Biológicas e da Saúde, Herbário UNOP, R. Universitária 2069, 85819-110, Cascavel, PR, Brasil.

${ }^{3}$ Universidade Estadual de Feira de Santana, Depto. Ciências Biológicas, Programa de Pós-Graduação em Botânica, BR 116, km 3, 44036-460, Feira de Santana, BA, Brasil.

${ }^{4}$ Universidade Federal de Viçosa, Depto. Biologia Vegetal, Av. P.H. Rolphs s/n, 36571-000, Viçosa, MG, Brasil.

${ }^{5}$ Autor para correspondência: cristianesnak@hotmail.com.
} 
racemosa, com flores bissexuadas e diclamídeas, prefloração imbricada ou valvar, ovário súpero, frequentemente unicarpelar e unilocular, com um a numerosos óvulos em placentação marginal. Fruto tipicamente legume, mas também pode apresentarse de outros tipos, como drupa, sâmara, folículo, craspédio ou lomento (Barroso et al. 1991; Lewis et al. 2005; Queiroz 2009).

A família apresenta grande importância econômica e pode ser comparada apenas a Poaceae, contudo o espectro de uso das leguminosas é muito maior (Kirkbride-Jr et al. 2003). São importantes nos ciclos biogeoquímicos e muitas espécies são características de vegetação aberta e ambientes perturbados, por serem adaptadas à primeira colonização e exploração de tais ambientes (Lewis 1987).

O estado do Paraná, ao longo de sua história, sofreu uma drástica perda de sua vegetação devido às atividades antrópicas, principalmente na região Oeste onde as terras são mais favoráveis às atividades agrícolas, sendo que hoje restam menos de $9 \%$ da cobertura vegetal original em bom estado de conservação (Roderjan et al. 2002). Concomitante a isto, a região Oeste é uma das áreas menos amostradas em termos botânicos no estado, principalmente se tratando da família Leguminosae. Tendo em vista que o Parque Ecológico Paulo Gorski é um dos poucos resquícios de mata original que restaram na região, o presente trabalho teve como objetivo realizar um levantamento florístico das espécies de Leguminosae, fornecer chave de identificação, descrições, comentários taxonômicos, distribuição geográfica, dados de floração e frutificação e ilustrações, contribuindo desta forma para o conhecimento da flora de leguminosas no Paraná.

\section{Material e Métodos}

O levantamento foi realizado no Parque Ecológico Paulo Gorski (245' 14 " a 24 $58^{\circ}$ ' 17'S, $53^{\circ} 25^{\prime} 14^{\prime \prime}$ a $\left.53^{\circ} 27^{\prime} 06^{\prime \prime} \mathrm{W}\right)$, no município de Cascavel, oeste do Paraná, com uma área de 111,26 ha (sendo 55,35 ha de mata nativa) e altitude média de 800 metros (FUNDETEC 1995). O clima na reigão é classificado como subtropical $(\mathrm{Cfa})$, com verões quentes, geadas pouco frequentes e concentração das chuvas geralmente nos meses de verão, no entanto sem estação seca definida (IAPAR 2000). O Parque representa uma área de transição entre a Floresta
Estacional Semidecidual e a Floresta Ombrófila Mista (Veloso et al. 1991; IBGE 1992).

Para coleta do material botânico foram realizadas visitas mensais, no período de outubro de 2007 a dezembro de 2008, ao longo de trilhas preexistentes na área. $\mathrm{O}$ material coletado foi herborizado segundo técnicas descritas por Bridson \& Forman (2004) e encontra-se depositado no herbário da Universidade Estadual do Oeste do Paraná (UNOP), além de duplicatas enviadas aos herbários MBM e VIC.

O sistema de classificação adotado para família, subfamílias e gêneros está de acordo com o utilizado por Lewis et al. (2005) e Queiroz (2009). Para a descrição das estruturas vegetativas e reprodutivas utilizou-se Radford et al. (1974), Polhill \& Raven (1981), Barroso et al. (1999) e Queiroz (2009). Os nomes dos autores foram abreviados de acordo com Brummit \& Powell (1992).

As diagnoses dos gêneros basearam-se na literatura e as diagnoses das espécies nas variações morfológicas observadas no material coletado no Parque Ecológico Paulo Gorski, e estão padronizadas de acordo com a subfamília. Quando necessário, para complementação das diagnoses, exsicatas de outros locais foram analisadas e listadas como material adicional, dando preferência aos espécimes coletados no mesmo tipo de vegetação do local de estudo. Adicionalmente foram consultadas as coleções dos herbários, MBM, UEC, UPCB e VIC acrônimos segundo Thiers (2012). Para as ilustrações botânicas foram apenas selecionados caracteres importantes para a identificação das espécies.

Os comentários sobre a distribuição geográfica foram baseados em literatura e dados das etiquetas dos espécimes observados nos herbários visitados. Os comentários sobre floração e frutificação foram baseados nas observações em campo, que foram feitas mensalmente ao longo de todo o período do estudo. Os nomes comuns estão de acordo com o utilizado na região.

\section{Resultados e Discussão}

No Parque Ecológico Paulo Gorski a família Leguminosae está representada por 29 espécies, reunidas em 26 gêneros. Senna Mill., foi o gênero mais representativo, com três espécies, seguido de Desmodium Desv., com duas espécies. Os demais gêneros foram representados na área por uma espécie cada. 
Chave para identificação das espécies de Leguminosae no Parque Ecológico Paulo Gorski, Cascavel - PR

1. Folhas bipinadas.

2. Folhas com 1 par de folíolos.

3. Inflorescências em glomérulo piramidal, estames mais de 20, acima de $2,5 \mathrm{~cm}$ compr., bicolores, fruto legume ............................................................. 2.4. Calliandra brevipes

3'. Inflorescências em glomérulo esferóide, estames 4, até $1 \mathrm{~cm}$ compr., monocolores, fruto craspédio

2.8. Mimosa flocculosa

2'. Folhas com mais de 1 par de folíolos.

4. Presença de nectários foliares, inflorescências em espiga, glomérulos esferóides ou piramidais.

5. Inflorescências em espiga

2.9. Parapiptadenia rigida

5'. Inflorescências em glomérulos esferóides ou piramidais.

6. Frutos do tipo folículo

2.3. Anadenanthera colubrina

6'. Frutos do tipo legume.

7. Estames 10

2.7. Leucaena leucocephala

7'. Estames mais de 40.

8. Legume bacáceo

2.5. Enterolobium contortisiliquum

8'. Legume deiscente.

9. Inflorescências do tipo glomérulo piramidal .... 2.2. Albizia niopoides

9'. Inflorênscencias do tipo glomérulo esferoide.

10. Ramos aculeados

2.10. Senegalia recurva

10'. Ramos inermes

2.1. Acacia mearnsii

4'. Ausência de nectários foliares, inflorescências racemosas ou paniculadas.

11'. Frutos do tipo legume.

12. Folhas $15-19$ folioladas, legumes deiscentes

1.5. Poincianella pluviosa

12'. Folhas 5-11 folioladas, legumes indeiscentes 1.3. Libidibia ferrea

11. Frutos dos tipos sâmara ou criptosâmara.

13. Ramos tomentosos, sâmaras

1.4. Peltophorum dubium

1'. Folhas não bipinadas.

13'. Ramos pubérulos, criptossâmaras

1.6. Schizolobium parahyba

14. Folhas $2-3$ folioladas.

15. Folhas 2-folioladas.

16. Folíolos concrescidos parcialmente, corola alva ou lilás, fruto legume

16'. Folíolos livres, corola amarela, fruto lomento

1.1. Bauhinia variegata 3.9. Zornia curvata

15'. Folhas 3-folioladas.

17. Arbusto ou arvoreta, ramos aculeados, folíolos maiores que $10 \mathrm{~cm}$ de compr., corola vermelha 3.3. Erythrina speciosa

17'. Subarbusto ou erva volúvel, ramos inermes, folíolos menores que $10 \mathrm{~cm}$ de compr., corola lilás ou rosada.

18. Erva volúvel, pétalas da quilha torcidas lateralmente, fruto legume

18'. Subarbusto, pétalas da quilha planas, fruto lomento.

19. Subarbusto prostrado, folíolos obovados, corola lilás

3.2.1. Desmodium adscendens

19'. Subarbusto ereto, folíolos ovados, corola rosada ... 3.2.2. Desmodium affine

14'. Folhas 4-multifolioladas.

20. Folhas com ausência de nectários foliares.

21. Folhas paripinadas

22. Folhas $8-24$ folioladas, margem inteira, flores amarelas; legume

1.2. Cassia leptophylla

22'. Folhas 48-54 folioladas, margem serreada, flores verdes; drupa 3.4. Holocalyx balansae

21'. Folhas imparipinadas. 
23. Foliolos oblongos.

24. Flores creme, sâmara com núcleo seminífero central

3.1. Dalbergia nigra

24'. Flores amarelas, sâmara com núcleo seminífero basal

3.8. Tipuana tipu

23'. Folíolos elípticos ou oblanceolados.

25. Foliolos elípticos; flores creme, estames monadelfos; sâmara ..... 3.5. Machaerium stipitatum

$25^{\prime}$. Folíolos oblanceolados; flores vermelhas ou alaranjadas; estames diadelfos; legume

3.6. Sesbania punicea

20'. Folhas com presença de nectários foliares

26. Folhas com a raque alada; inflorescência em espiga, legumes tomentosos 2.6. Inga virescens

26'. Folhas com a raque não alada, inflorescência em racemos ou paniculas, legumes glabros

27. Folhas 4-foliolada 1.7.1. Senna macranthera

27'. Folhas 8-24-folioladas.

28. Árvore, nectários foliares entre os folíolos do primeiro par e nos folíolos dos pares distais 1.7.2. Senna multijuga

28'. Arbusto, nectários foliares somente entre os folíolos do primeiro par

1.7.3. Senna pendula

\section{Caesalpinioideae \\ 1.1. Bauhinia variegata L., Sp. Pl. 1: 375.1753}

Fig. 1a

Árvore 4-5 m alt., ramo cilíndrico, pubérulo, inerme. Estípula 2-3 mm compr., lanceolada, tomentosa, caduca; pecíolo 1,5-2,5 cm compr.; nectário foliar ausente. Folha paripinada, 2foliolada, aparentemente simples; folíolos 2,5-8,2 $\times 3-4,2 \mathrm{~cm}$, concrescidos parcialmente, base oblíqua, ápice arredondado, margem inteira, face adaxial glabra, abaxial pubérula. Inflorescência racemosa, axilar. Cálice verde, gamossépalo, lacínios nulos, espatáceo, 12-20 mm compr., estrigoso externamente. Corola alva ou lilás, pétala centro-adaxial 47-60 mm compr. Estames 5, livres, heterodínamos, 25-45 mm compr., estaminódio ausente. Ovário 15-20 mm compr., estrigoso a piloso, estípite 15-18 mm compr.; estilete 12-15 mm compr., pubérulo. Legume deiscente, 11-20 $\times 1-2 \mathrm{~cm}$, glabro; 3-7 sementes, ca. $10 \times 6 \mathrm{~mm}$, ovadas, castanhas.

Material examinado: 19.X.2007, C. Snak \& Q.C. Bortoli 39 (UNOP); 22.IV.2008, fl. e fr., C. Snak \& A. Snak 114 (UNOP); 22.IV.2008, fl. e fr., C. Snak \& A. Snak 115 (UNOP); 5.V.2008, fl., C. Snak \& L.P. Poli 136 (UNOP).

Bauhinia variegata é popularmente conhecida como pata-de-vaca. Pode ser distinguida das demais Leguminosae presentes no Parque por apresentar os dois folíolos concrescidos parcialmente. Indivíduos cultivados de $B$. variegata podem apresentar flores com pétalas alvas ou liláses, tratando-se apenas de uma variação intraespecífica (Bortoluzzi et al. 2006). A espécie é originária da Ásia (Roskov et al. 2005), mas amplamente cultivada em todo o Brasil com fins ornamentais (Bortoluzzi et al. 2006). A floração ocorre durante vários meses do ano principalmente nos meses de inverno, podendo se estender até a primavera o que a diferencia das espécies nativas em que a floração ocorre no verão. $\mathrm{Na}$ área de estudo a floração ocorreu de abril a outubro e foi encontrada com frutos no mesmo período.

1.2. Cassia leptophylla Vogel, Gen. Cass. Syn. 13. 1837.

Fig. 1b-c

Árvore ca. $12 \mathrm{~m}$ alt., ramo anguloso, glabro, inerme. Estípula 3-4 mm compr., lanceolada, tomentosa, caduca; pecíolo 2,5-5,5 cm compr.; raque 7-27 cm compr.; nectário foliar ausente. Folha paripinada, 8-24-foliolada; folíolos 4-7 $\times$ 1,8-2,5 cm, elípticos, base oblíqua, ápice agudo, margem inteira, face adaxial pubérula, abaxial glabrescente. Inflorescência racemosa, terminal. Cálice verde, dialissépalo, 5 sépalas, 10-15 $\mathrm{mm}$ compr., glabrescente externamente. Corola amarela, pétala centro-adaxial $30-40 \mathrm{~mm}$ compr. Estames 7, livres, heterodínamos (3 adaxiais 25-33 mm compr., sigmoides, com uma dilatação em forma de um nódulo elipsoide nos filetes, 4 medianos 10-14 m compr.), estaminódios 3. Ovário 35-39 mm compr., pubérulo, estípite 7-11 mm compr.; estilete 3-5 mm compr., pubérulo. Legume indeiscente, $20-50 \times 1,5-2,3 \mathrm{~cm}$, glabro; 43-110 sementes, $10-13 \times 5-8 \mathrm{~mm}$, ovadas, castanhas. Material examinado: 5.V.2008, fr., C. Snak \& L.P. Poli 160 (UNOP); 21.XI.2008, fl., C. Snak \& A. Snak 213 (UNOP).

Cassia leptophylla é popularmente conhecida como cássia ou falso-barbatimão. Pode ser facilmente reconhecida na área de estudo por apresentar três 


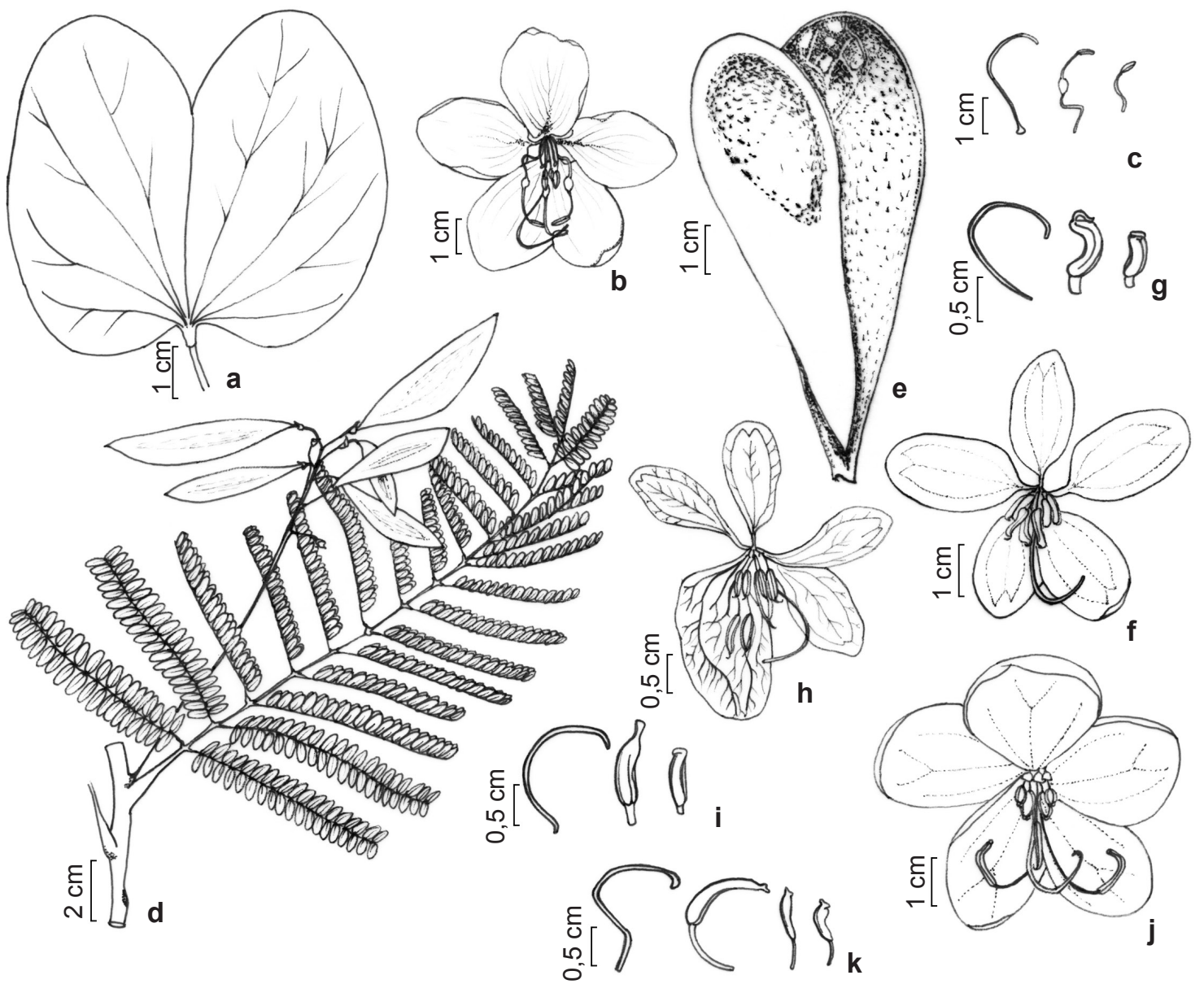

Figura 1 - a-k. Caesalpinioideae - a. Bauhinia variegata - folha (C. Snak 136). b-c. Cassia leptophylla -b. flor; c. gineceu e estame adaxial e mediano (C. Snak 213). d. Peltophorum dubium - ramo com frutos (C. Snak 91). e. Schizolobium parahyba - fruto (C. Snak 190). f-g. Senna macranthera - f. flor; g. gineceu e estames adaxial e mediano (C. Snak 102). h-i. S. multijuga - h. flor; i. gineceu e estames latero-abaxial e mediano (C. Snak 39). j-k. S. pendula - j. flor. k. gineceu e estames centro-abaxial, latero-abaxial e mediano (C. Snak 104).

Figure 1 -a-k. Caesalpinioideae - a. Bauhinia variegata - leaves (C. Snak 136). b-c. Cassia leptophylla -b. flower; c. gynoecium and stamen adaxial and median (C. Snak 213). d. Peltophorum dubium - branch with fruits (C. Snak 91). e. Schizolobium parahyba - fruit (C. Snak 190). f-g. Senna macranthera - f. flower, g. gynoecium and stamens adaxial and median (C. Snak 102). h-i. S. multijuga - h. flower, i. gynoecium and stamens lateralabaxial and median (C. Snak 39). j-k. S. pendula -j. flower; k. gynoecium and stamens central-abaxial, lateral-abaxial and median (C. Snak 104).

estames com filetes sigmoides e legume indeiscente. A espécie é endêmica do Brasil e ocorre naturalmente no Paraná, Rio Grande do Sul, Santa Catarina e São Paulo, em Floresta Estacional Semidecidual, Floresta Ombrófila e Floresta Ombrófila Mista (Souza \& Bortoluzzi 2012a). Floresce de julho a dezembro e frutifica em maio.

1.3. Libidibia ferrea (Mart. ex Tul.) L.P.Queiroz, Legum. Caatinga. 130. 2009.

Árvore ca. $6 \mathrm{~m}$ alt., ramo cilíndrico, glabro, inerme. Estípula ca. $2 \mathrm{~mm}$ compr., lanceolada, glabrescente, caduca; pecíolo 2-2,5 cm compr.; raque $2-8 \mathrm{~cm}$ compr.; nectário foliar ausente. Folha bipinada, imparipinada, 5-11-foliolada; foliólulos $1-1,6 \times 0,5-0,7 \mathrm{~cm}$, oblongos, base oblíqua, ápice retuso, margem inteira, face adaxial esparsamente pilosa, abaxial pilosa. Inflorescência paniculada, terminal ou axilar. Cálice verde, dialissépalo, 5 sépalas, 5-7 $\mathrm{mm}$ compr., glabros externamente. Corola amarela, pétala centro-adaxial $5-8 \mathrm{~mm}$ compr. Estames 10, livres, isodínamos, 7-10 mm compr., estaminódio ausente. Ovário 3-4 mm compr., glabro, estípite ca. $2 \mathrm{~mm}$; estilete ca. 10 
mm compr., glabro. Legume indeiscente, 5-7 $~ 5$ 2-2,5 cm, glabro; 1-5 sementes, ca. $7 \times 6 \mathrm{~mm}$, ovadas, negras.

Material examinado: 28.XI.2007, fl., C. Snak 48 (UNOP); 28.VII.2008, fr., C. Snak \& A. Snak 173 (UNOP).

Libidibia ferrea foi segregada recentemente do gênero Caesalpinia L. por Queiroz (2009) e é popularmente conhecida como pau-ferro. Caracteriza-se na área de estudo por apresentar as folhas bipinadas, inflorescência paniculada e legume indeiscente. A espécie foi introduzida na área e ocorre naturalmente no Nordeste e Sudeste do Brasil em Caatinga, Cerrado, Mata Atlântica (Lewis 2012a). Floresceu em novembro e frutificou em julho.

1.4. Peltophorum dubium (Spreng.) Taub., Natürl. Pflanzenfam. 3(3): 176. 1892.

Fig. 1d

Árvore 7-8 m alt., ramo anguloso, tomentoso ferrugíneo, inerme. Estípula não observada, caduca; pecíolo 2-3,5 cm compr.; raque 10-20 cm compr.; nectário foliar ausente. Folha bipinada, paripinada, 16-32-foliolada; foliólulos $0,6-1,2 \times 0,3-0,5$ $\mathrm{cm}$, oblongos, base oblíqua, ápice mucronulado, margem inteira, ciliada, face adaxial glabra, abaxial glabrescente. Inflorescência paniculada, terminal. Cálice castanho, dialissépalo, 5 sépalas, 5-7 mm compr., tomentoso externamente. Colora amarela, pétala centro-adaxial, $10-15 \mathrm{~mm}$ compr.; estames 10, livres, heterodínamos, 3-7 mm compr., estaminódio ausente. Ovário 3-5 $\mathrm{mm}$ compr., seríceo, estípite ca. $2 \mathrm{~mm}$ compr.; estilete ca. $3 \mathrm{~mm}$ compr., glabro. Sâmara, 5-7 × 1,3-1,7 cm, pubérula; 1-2 sementes, 7-10 × 4-6 mm, ovadas, castanhas. Material examinado: 12.XII.2007, fl., C. Snak 61 (UNOP); 25.II.2008, fr., C. Snak \& A. Snak 91 (UNOP).

Peltophorum dubium é popularmente conhecida como canafístula. Caracteriza-se pelo indumento tomentoso ferrugíneo nos ramos, folhas bipinadas e fruto do tipo sâmara. Ocorre de forma natural na Argentina, Brasil, Paraguai e Uruguai (Roskov et al. 2005). No Brasil, ocorre no Nordeste, Centro-Oeste, Sudeste e Sul em Caatinga, Cerrado, Mata Atlântica e Pantanal (Lewis 2012b). Floresce de novembro a julho e frutifica de fevereiro a maio.

1.5. Poincianella pluviosa (DC.) L.P.Queiroz, Legum. Caatinga. 126. 2009.

Árvore 3-5 m alt., ramo cilíndrico, glabro, inerme. Estípula 3-5 mm compr., cimbiforme, pubescente, caduca; pecíolo $2-2,5 \mathrm{~cm}$ compr.; raque 6-10,5 cm compr.; nectário foliar ausente. Folha bipinada, 15-19-foliolada; foliólulos 0,5-0,8 $\times 0,3-0,5 \mathrm{~cm}$, obovados, base oblíqua, ápice arredondado a obtuso, margem inteira, ambas as faces glabras. Inflorescência racemosa, terminal. Cálice amarelo, dialissépalo, 5 sépalas, 4-6 mm compr., tomentosas externamente. Corola amarela, pétala centro-adaxial 5-7 $\mathrm{mm}$ compr. Estames 10, livres, heterodínamos, $12-13 \mathrm{~mm}$ compr., estaminódio ausente. Ovário 3-4 mm compr., piloso (glandular), estípite ca. $1 \mathrm{~mm}$ compr.; estilete ca. $8 \mathrm{~mm}$ compr., glandular. Legume deiscente, $10-12,5 \times 2-2,5 \mathrm{~cm}$, glabro; $3-5$ sementes, ca. 15 $\times 10 \mathrm{~mm}$, ovadas, castanhas.

Material examinado: 17.V.2008, fr., C. Snak et al. 126 (UNOP); 28.VIII.2008, fl., C. Snak \& L.P. Poli 192 (UNOP).

Poincianella pluviosa, recentemente segregada do gênero Caesalpinia por Queiroz (2009), é popularmente conhecida como sibipiruna. Pode ser reconhecida no Parque pelas folhas bipinadas, inflorescência racemosa e legume deiscente. A espécie ocorre de forma natural no norte da Argentina, Bolívia, Paraguai e no Brasil nos estados da Bahia, Espírito Santo, Mato Grosso, Mato Grosso do Sul, Minas Gerais, Pará, Paraná, Paraíba, Pernambuco e Rio de Janeiro em Floresta Amazônia, Caatinga, Cerrado, Mata Atlântica e Pantanal (Lewis \& Gibbs 1999; Lewis 2012c). Floresce de janeiro a novembro e frutifica de maio a junho.

1.6. Schizolobium parahyba (Vell.) S.F. Blake, Contr. U.S. Natl. Herb. 20(7): 240. 1919.

Figs. 1e, 4a

Árvore ca. $20 \mathrm{~m}$ alt., ramo cilíndrico, pubérulo, inerme. Estípula não vista, caduca; pecíolo $11-16 \mathrm{~cm}$ de compr.; raque 30-50 cm compr.; nectário foliar ausente; Folha bipinada, paripinada, 34-40-foliolada; foliólulos ca. $1 \times 0,4 \mathrm{~cm}$, elípticos, base oblíqua, ápice acuminado, margem inteira, ambas as faces glabras. Inflorescência racemosa, terminal. Cálice castanho, dialissépalo, 5 sépalas, $8-11 \mathrm{~mm}$ compr., tomentoso externamente. Corola amarela, pétala centro-adaxial 8-13 mm compr. Estames 10, livres, isodínamos, $13-15 \mathrm{~mm}$ compr., estaminódio ausente. Ovário 4-5 mm compr., tomentoso, estípite 3-4 mm compr., tomentoso; estilete 5-7 mm compr., glabro. Criptossâmara, ca. $11 \times 4$ cm, glabra; 1 semente, ca. $27 \times 15 \mathrm{~mm}$, elipsoide, castanha.

Material examinado: 28.VII.2008, fr., C. Snak \& L.P. Poli 190 (UNOP); fl., 29.X.2008, C. Snak 210 (UNOP).

Schizolobium parahyba é popularmente conhecida como guapuruvu. Pode ser reconhecida na área por apresentar o fruto do tipo criptossâmara. Espécie nativa da América Tropical, ocorrendo 
no Brasil, México, Nicarágua, Panamá, Paraguai (Roskov et al. 2005). No Brasil, ocorre na Região Norte em Floresta Amazônia e da Bahia até Santa Catarina em Floresta Ombrófila Densa e Floresta Estacional Semidecidual (Lima et al. 2009; Lewis 2012d). Floresce e frutifica de novembro a janeiro, também foram observados frutos em julho.

\subsection{Senna Mill.}

Árvores, arbustos ou subarbustos. Folhas paripinadas. Nectário foliar presente no pecíolo e/ ou entre os folíolos que formam os pares, raramente ausente. Inflorescências racemosas ou paniculadas, axilares ou terminais. Flores zigomorfas ou assimétricas. Cálice dialissépalo. Corola dialipétala, amarela; estames 7, heterodínamos, geralmente 3 abaxiais, 4 medianos e 3 estaminódios adaxiais. Legume deiscente ou indeiscente.

1.7.1. Senna macranthera (Collad.) H.S. Irwin \& Barneby, Mem. New York Bot. Gard. 35: 181. 1982.

Figs. 1f-g, 4b

Árvore ca. 5m alt., ramo anguloso, tomentoso, inerme. Estípula não observada, caduca; pecíolo 2-3,5 cm compr.; raque 1-2,5 cm compr.; nectário foliar entre os folíolos do primeiro par, cônico. Folha 4-foliolada; folíolos proximais $4-6,5 \times 2,5-3,5 \mathrm{~cm}$, folíolos distais 7,5-13 × 3-5,5 cm, obovados, base oblíqua, ápice acuminado, margem inteira, face adaxial estrigosa a glabrescente, face abaxial tomentosa. Inflorescência se paniculada, terminal ou racemosa, então axilar. Cálice verde, dialissépalo, 5 sépalas, 3-5 mm compr., seríceas externamente. Corola amarela, pétala centro-adaxial 30-35 mm compr. Estames 7, livres, heterodínamos (3 abaxiais 11-15 mm compr., 4 medianos 7-9 mm compr.), estaminódios 3. Ovário 25-30 mm compr., tomentoso, estípite 3-4 mm compr.; estilete 2-4 mm compr., tomentoso. Legume indeiscente, $20-30 \times 0,5-1$ $\mathrm{cm}$, glabrescente, sementes numerosas, ca. $5 \times 3 \mathrm{~mm}$, ovadas, castanhas.

Material examinado: 7.I.2008, fl., C. Snak \& A. Snak 77 (UNOP); 29.III.2008, fl. efr., C. Snak \&A. Snak 102 (UNOP).

Senna macranthera é popularmente conhecida como fedegoso ou aleluia. Caracteriza-se no Parque por apresentar folhas com dois pares de folíolos, sendo os proximais de menores dimensões e estames heterodínamos. A espécie foi introduzida na área e ocorre de forma natural na Venezuela, Equador, Peru e no Brasil desde o Piauí até o Paraná em Caatinga, Cerrado e Floresta Ombrófila (Irwin \& Barneby 1982; Souza \& Bortoluzzi 2012b). Esta espécie apresentou-se com flores de janeiro a março e frutificou em março.
1.7.2. Senna multijuga (Rich.) H.S. Irwin \& Barneby, Mem. New York Bot. Gard. 35(2): 492. 1982.

Figs. $1 \mathrm{~h}-\mathrm{i}, 4 \mathrm{c}$

Árvore ca. $6 \mathrm{~m}$ alt., ramo levemente anguloso, glabro, inerme. Estípula 3-4 mm compr., linear, caduca; pecíolo 1,5-2 cm compr.; raque 5,5-12 cm compr., nectário foliar entre os folíolos do primeiro par e entre os folíolos dos pares distais, fusiforme. Folha 8-24-foliolada; folíolos 1-3 × 0,5-1,2 cm, oblanceolados a oblongos, base oblíqua, ápice retuso, margem inteira, ambas as faces pubérulas. Inflorescência se paniculada, terminal ou racemosa, então axilar. Cálice amarelo, dialissépalo, 5 sépalas, 2-8 mm compr., glabras externamente. Corola amarela, pétala centro-adaxial $18-25 \mathrm{~mm}$ compr. Estames 7, livres, heterodínamos (2 latero-abaxiais 10-15 mm compr., 1 centro-abaxial $8-10 \mathrm{~mm}$ compr., 4 medianos 5-7 mm compr.), estaminódios 3. Ovário $15-20 \mathrm{~mm}$ compr., glabro, estípite ca. $3 \mathrm{~mm}$ compr.; estilete ca. $1 \mathrm{~mm}$ compr., glabro. Legume deiscente, $8-10 \times 1,7-1,9 \mathrm{~cm}$, pubérulo; 14-20 sementes, ca. $8 \times 3 \mathrm{~mm}$, oblongas, castanhas. Material examinado: 28.XI.2007, fl., C. Snak 39 (UNOP); 28.VIII.2008, fr., C. Snak \& L.P. Poli 186 (UNOP).

Senna multijuga é popularmente conhecida como pau-cigarra. Caracteriza-se pelo hábito arbóreo, folíolos oblanceolados a oblongos e flores amarelas. Ocorre em todo o Brasil na Amazônia, Caatinga, Cerrado e Mata Atlântica (Souza \& Bortoluzzi 2012b). Floresce e frutifica de novembro a abril.

1.7.3. Senna pendula (Willd.) H.S. Irwin, Mem. New York Bot. Gard. 35(1): 378. 1982.

Figs. $1 \mathrm{j}-\mathrm{k}, 4 \mathrm{~d}$

Arbusto ca. $3 \mathrm{~m}$ alt., ramo cilíndrico, pubérulo, inerme. Estípula ca. $1 \mathrm{~mm}$ compr., linear, caduca; pecíolo 1,5-2,5 cm compr.; raque 2,5-5 cm compr.; nectário foliar entre os folíolos do primeiro par, cônico. Folha 8-10-foliolada; folíolos 1,8-3 × 1,3-1,5 cm, obovados, base oblíqua, ápice obtuso, margem inteira, ambas as faces glabras. Inflorescência racemosa, axilar. Cálice verde, dialissépalo, 5 sépalas, $6-10 \mathrm{~mm}$ compr., pubérulas externamente. Corola amarela, pétala centro-adaxial 15-20 mm compr. Estames 7, livres, heterodínamos (1 abaxial central 15-17 mm compr., 2 latero-abaxiais $25-30 \mathrm{~mm}$ compr., 4 medianos 7-8 $\mathrm{mm}$ compr.), estaminódios 3 . Ovário 2,3-3 $\mathrm{mm}$ compr., pubescente, estípite 2-4 mm compr.; estilete ca. $6 \mathrm{~mm}$ compr., glabro. Legume deiscente, $8-12 \times 0,5-1,3 \mathrm{~cm}$, glabro; 30-50 sementes, ca. $5 \times 3 \mathrm{~mm}$, oblongas, negras. 
Material examinado: 29.III.2007, fl., C. Snak \& $A$. Snak 104 (UNOP); 28.VII.2008, fr., C. Snak \& A. Snak 174 (UNOP).

Senna pendula é popularmente conhecida como fedegoso ou canudo-de-pito. Caracteriza-se pelo hábito arbustivo e folíolos obovados. Nativa desde o México até a Argentina (Irwin \& Barneby 1982). É amplamente distribuída no Brasil na Amazônia, Caatinga, Cerrado, Mata Atlântica e Pantanal (Souza \& Bortoluzzi 2012b). Floresce de fevereiro a maio, frutifica de abril a julho.

\section{Mimosoideae}

2.1. Acacia mearnsii De Wild., Pl. Bequaert. 3(1): 61. 1925.

Figs. 2a, 4e

Árvore 8-12 m alt., ramo anguloso, tomentoso, inerme. Estípula ca. $1 \mathrm{~mm}$ compr., lanceolada, tomentosa, caduca; pecíolo 2-2,5 cm compr.; raque 4-7 cm compr., não alada; nectário foliar no pecíolo e entre os pares de folíolos, esferoide. Folha 16-42-foliolada; foliólulos ca. $0,3 \times 0,1 \mathrm{~cm}$, oblanceolados, base oblíqua, ápice arredondado, margem inteira, ciliada, face adaxial glabra, abaxial pubérula. Inflorescência glomérulo esferóide, axilar. Cálice creme, gamossépalo, 5-laciniado, lacínios ca. 1,2 mm compr., pubescentes externamente. Corola creme, pétalas $2 \mathrm{~mm}$ compr. Estames numerosos, livres, isodínamos, monocolores (creme), ca. 4 mm compr., estaminódio ausente. Ovário ca. 0,7 mm compr., glabro, não estipitado; estilete ca. 4,5 $\mathrm{mm}$ compr., glabro. Legume deiscente, ca. 4-6 $\times$ $0,5 \mathrm{~cm}$, tomentoso; 3-12 sementes, ca. $2 \times 1 \mathrm{~mm}$, obovóides, negras.

Material examinado: 29.IX.2007, fl., C. Snak et al. 08 (UNOP); 22.IV.2008, fr., C. Snak \& A. Snak 110 (UNOP); 28.VII.2008, fl., C. Snak \& A. Snak 172 (UNOP).

Acacia mearnsii é popularmente conhecida como acácia-negra. Caracteriza-se na área de estudo pelo tronco fissurado e presença de um nectário entre cada par de folíolos. A espécie é originária da Austrália e amplamente difundida por se tratar de uma árvore ornamental de grande beleza, além de ser utilizada para extração de tanino (Burkart 1979; Rico-Arce 2007). Floresce de junho a novembro, frutifica de novembro a abril.

2.2. Albizia niopoides (Spruce ex Benth.) Burkart, Legum. Argent. 2: 542. 1952.

Árvore 3,5 m alt., ramo cilíndrico, pubérulo, inerme. Estípula não vista, caduca; pecíolo 2-4,5 cm compr.; raque 3,5-8 cm compr., não alada; nectário foliar no pecíolo e entre os folíolos do par distal, discóide. Folha bipinada, 10-16-foliolada; foliólulos ca. 0,3-0,6 ×0,1 cm, lineares, base truncada, ápice agudo, margem inteira, ciliada, ambas as faces glabras. Inflorescência em glomérulo piramidal agrupado em panícula, axilar. Cálice verde, gamossépalo, 5-laciniado, lacínios 1-1,2 mm compr., pubérulo externamente. Corola cremeesverdeada, pétalas ca. $3 \mathrm{~mm}$ compr. Estames numerosos, monadelfos, isodínamos, monocolores (alvos), ca. $8 \mathrm{~mm}$ compr., estaminódio ausente. Ovário ca. 0,5 mm compr., glabro, não estipitado; estilete 6-8 mm compr., glabro. Legume deiscente ca. $7 \times 1,5 \mathrm{~cm}$, glabro; sementes não vistas.

Material examinado: 8.XII.1988, fl., J. da Cruz 203 (UEC).

Material adicional examinado: PARANÁ: Porto Rico, margem do Rio Paraná, 16.I.1987, fl., L.H.S Silva \& F.C. Silva 43 (HUEFS); SÃO PAULO: São Paulo, Campus da USP, 3.XII.1996, fl. e fr., L.P. de Queiroz 4732 (HUEFS).

Albizia niopoides é popularmente conhecida como angico-branco ou pau-mulata, pode ser reconhecida na área de estudo por apresentar as folhas geralmente com oito pares de pinas, foliólulos lineares com a base truncada e glomérulo piramidal agrupados em panícula. A espécie ocorre naturalmente na América Central e América do Sul (Rico-Arce 1992), no Brasil a espécie está restrita as regiões sul, centro-oeste e aos estados de São Paulo, Minas Geais, Pará e Maranhão, na Amazônia, Cerrado e Mata Atlântica (Iganci 2012). Floresce e frutifica nos meses do verão.

\subsection{Anadenanthera colubrina (Vell.) Brenan, Kew} Bull. 10(2): 182. 1955.

Fig. $2 b$

Árvore 10-15 m alt., ramo cilíndrico, pubérulo, inerme. Estípula não vista, caduca; pecíolo 3-7 cm compr.; raque 10-19 cm compr., não alada; nectário foliar no pecíolo e entre os folíolos dos pares distais, discóide. Folha bipinada, 26-38-foliolada; foliólulos ca. $0,5 \times 0,1 \mathrm{~cm}$, estreitamente elípticos, base oblíqua, ápice agudo, margem inteira, ciliada, ambas as faces glabras. Inflorescência glomérulo esferóide, axilar. Cálice verde, gamossépalo, 5-laciniado, lacínios 1-1,2 mm compr., pubescente externamente. Corola creme, pétalas 4-5 mm compr. Estames 10, livres, isodínamos, monocolores (alvos), 6-8 mm compr., estaminódio ausente. Ovário 1-1,2 mm compr., glabro, não estipitado; estilete 6-8 mm compr., glabro. Folículo $12-24 \times 1,4-2 \mathrm{~cm}$, glabro; 7-11 sementes, ca. $10 \times 10 \mathrm{~mm}$, orbiculares, castanhas. Material examinado: 22.IV.2008, fr., C. Snak \& A. Snak 112 (UNOP); 5.V.2008, fr., C. Snak \& L.P. Poli 145 (UNOP); 29.X.2008, fl., C. Snak 208 (UNOP). 


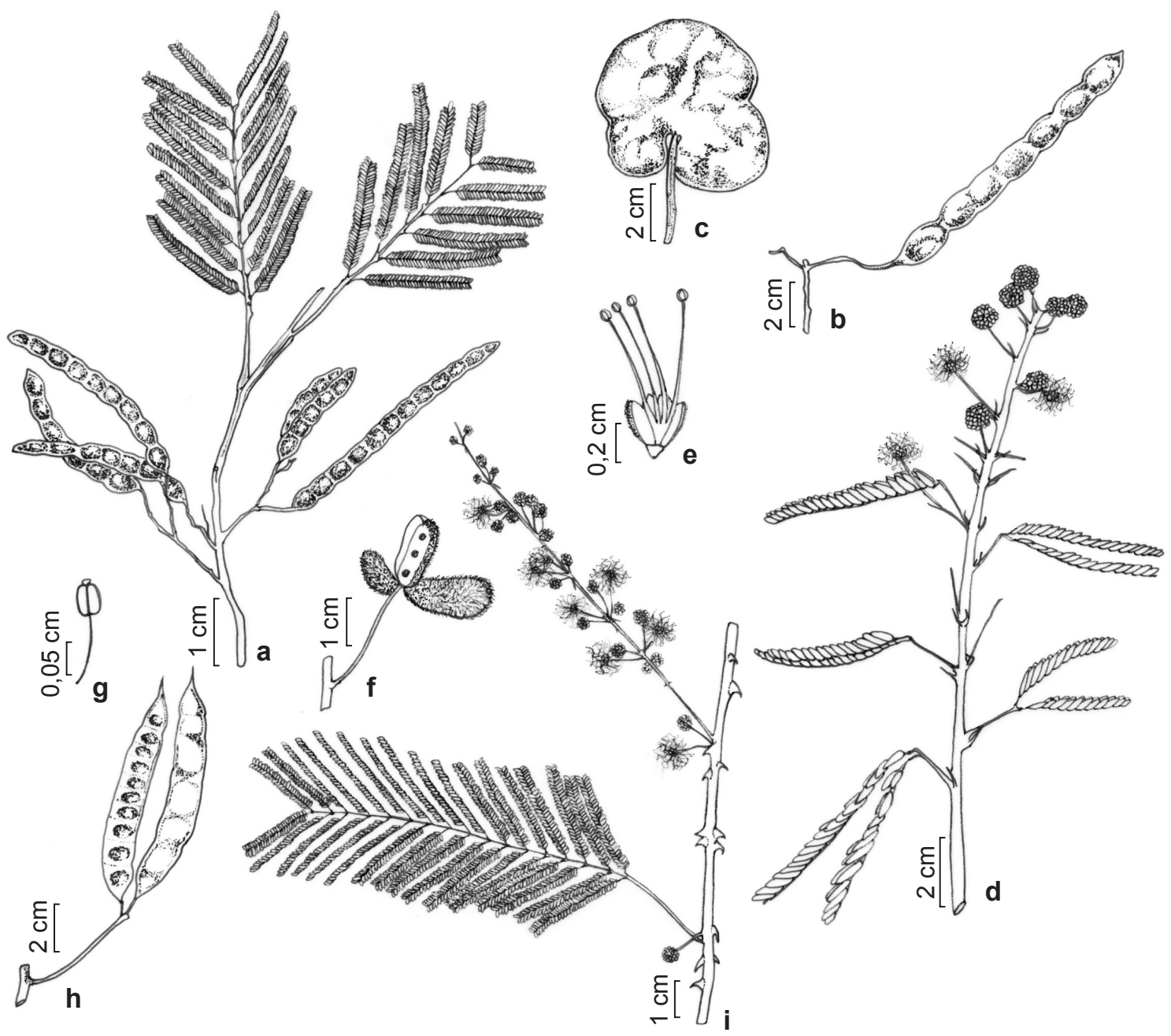

Figura 2 - a-i. Mimosoideae - a. Acacia mearnsii - ramo com frutos (C. Snak 110). b. Anadenanthera colubrina fruto (C. Snak 145). c. Enterolobium contortisiliquum - fruto (C. Snak 201). d-f. Mimosa flocculosa - d. ramo com inflorescência e flores; e. flor com androceu; f. frutos (C. Snak 105, C. Snak 127). g-h. Parapiptadenia rigida - g. estame; h. fruto deiscente (C. Snak 90, C. Snak 31). i. Senegalia recurva-ramo com inflorescência e flores (C. Snak60). Figure 2 - a-i. Mimosoideae - a. Acacia mearnsii - branch with fruits (C. Snak 110). b. Anadenanthera colubrina - fruit (C. Snak 145). c. Enterolobium contortisiliquum - fruit (C. Snak 201). d-f. Mimosa flocculosa - d. branch; e. flower with androecium; f. fruit (C. Snak 105, C. Snak 127). g-h. Parapiptadenia rigida - g. stamen; h. fruit dehiscent (C. Snak 90, C. Snak 31). i. Senegalia recurva - branch with inflorescence and flowers (C. Snak 60).

Anadenanthera colubrina é popularmente conhecida como angico. Pode ser reconhecida na área de estudo por apresentar fruto do tipo folículo e foliólulos muito pequenos, com cerca de $1 \mathrm{~mm}$ de largura. Ocorre de forma natural na Bolívia, Peru e no Brasil, nas regiões Nordeste, Centro-Oeste, Sudeste e no Paraná, em Caatinga, Cerrado e Mata Atlântica (Carvalho 2003; Morim 2012a). Floresce de novembro a fevereiro, ocasionalmente em abril e frutifica de abril a maio.
2.4. Calliandra brevipes Benth., J. Bot. (Hooker) 2: 140.1840.

Fig. $4 \mathrm{f}$

Arbusto ca. $2 \mathrm{~m}$ alt., ramo cilíndrico, glabro, inerme. Estípula ca. $1 \mathrm{~mm}$ compr., lanceolada, glabra, persistente; pecíolo 0,3-0,5 cm compr.; raque nula; nectário foliar ausente. Folha bipinada, 2-foliolada; foliólulos ca. $0,5 \times 0,1 \mathrm{~cm}$, estreitamente oblongos, base oblíqua, ápice arredondado, margem inteira, ambas as faces glabras. Inflorescência em glomérulo piramidal, axilar. Cálice rosado, gamossépalo, 
4-laciniado, lacínios ca. 0,2 mm compr., glabrescente externamente. Corola rosada, pétalas ca. $5 \mathrm{~mm}$ compr. Estames numerosos, monadelfos, bicolores (alvo e róseos), ca. $30 \mathrm{~mm}$ compr., estaminódio ausente. Ovário ca. $1 \mathrm{~mm}$ compr., glabro, não estipitado; estilete ca. $34 \mathrm{~mm}$ compr., glabro. Legume deiscente, 4-8 $\times 0,5-0,6 \mathrm{~cm}$, glabro; 3-7 sementes, ca. $6 \times 4 \mathrm{~mm}$, obladas, castanhas.

Material examinado: 25.II.2008, fl. e fr., C. Snak \& $A$. Snak 92 (UNOP).

Calliandra brevipes é popularmente conhecida como cabelo-de-anjo. A espécie é de fácil reconhecimento na área por apresentar a folha com um par de folíolos e estames bicolores. Ocorre naturalmente no sul do Brasil, Maranhão, Minas Gerais e Paraíba, na Amazônia, Caatinga, Cerrado, Mata Atlântica e Pampa (Souza 2012). Floresce e frutifica durante quase todo o ano.

\subsection{Enterolobium contortisiliquum (Vell.)} Morong, Ann. New York Acad. Sci. 7: 1021893.

Fig. 2c

Árvore ca. $10 \mathrm{~m}$ alt., ramo estriado, glabro, inerme. Estípula ca. $1 \mathrm{~mm}$ compr., lanceolada, glabra, caduca; pecíolo 3-5 cm compr.; raque 0-6 cm compr., não alada; nectário foliar no pecíolo, discóide a esferóide. Folha bipinada, 2-10-foliolada; foliólulos ca. 1,2 $\times 0,5 \mathrm{~cm}$, oblongos, base oblíqua, ápice agudo, margem inteira, ambas as faces pubérulas. Inflorescência em glomérulo piramidal, axilar. Cálice verde, gamossépalo, 5-laciniado, lacínios 1-1,2 mm compr., pubescente externamente. Corola verde, pétalas 4-6 mm compr. Estames numerosos, monadelfos, monocolores (alvos), 8-10 mm compr., estaminódio ausente. Ovário 2-2,2 mm compr., glabro, não estipitado; estilete 7-9 $\mathrm{mm}$ compr., glabro. Legume bacáceo, ca. $6 \times 6 \mathrm{~cm}$, glabro, indeiscente, ca. 18 sementes, ca. $10 \times 6 \mathrm{~mm}$, elipsóides, castanhas.

Material examinado: 28.VIII.2008, fr., C. Snak \& L.P. Poli 201 (UNOP); 29.X.2008, fl., C. Snak 209 (UNOP).

Enterolobium contortisiliquum é popularmente conhecida como orelha-de-macaco, orelha-de-negro ou tambori. Pode ser reconhecida facilmente na área pelo legume bacáceo. Ocorre de forma natural no norte e noroeste da Argentina, no sul da Bolívia, na Colômbia, no leste do Paraguai, no Peru e noroeste do Uruguai (Carvalho 2003). No Brasil tem ampla distribuição, ocorrendo desde o Piauí até o Rio Grande do Sul, na Caatinga, Cerrado e Mata Atlântica (Morim 2012b). A floração e a frutificação estão concentradas nos últimos meses do ano.
2.6. Inga virescens Benth., London J. Bot. 4: 605.1845

Árvore ca. $7 \mathrm{~m}$ alt., ramo cilíndrico, glabro, inerme. Estípula ca. $2 \mathrm{~mm}$ compr., lanceolada, serícea, caduca; pecíolo 0,5-1,5 cm compr.; raque 3-7 cm compr., alada; nectário foliar entre os folíolos de todos os pares, clavado. Folha paripinada, 4-8-foliolada, folíolos proximais ca. 5 $\times 1,5 \mathrm{~cm}$, distais ca. $13 \times 3,5 \mathrm{~cm}$, lanceolados, base oblíqua, ápice acuminado, margem inteira, ciliada, ambas as faces glabras. Inflorescência espiga, axilar. Cálice verde, gamossépalo, 5-laciniado, lacínios ca. $2 \mathrm{~mm}$ compr., pubescentes externamente. Corola verde, pétalas ca. $2 \mathrm{~mm}$ compr. Estames numerosos, monadelfos, monocolores (alvos), ca. $20 \mathrm{~mm}$ compr., estaminódio ausente. Ovário ca. $2 \mathrm{~mm}$ compr., glabro, não estipitado; estilete ca. $26 \mathrm{~mm}$ compr., glabro. Legume indeiscente, 6,5-7 × 1,5-2 $\mathrm{cm}$, tomentoso; sementes não vistas.

Material examinado: 13.IX.2008, fl., C. Snak et al. 202 (UNOP).

Material adicional examinado: PARANÁ: Curitiba, Parque Barigui, 6.I.1997, fr., C. Kozera 522 (UPCB).

Inga virescens é popularmente conhecida como ingá ou ingá-verde. Pode ser facilmente reconhecida na área pelos numerosos estames alvos e pela folha com a raque alada. Seus frutos apresentam sementes revestidas de polpa adocicada, muito apreciada pelos animais. A espécie é endêmica do Brasil, ocorrendo desde São Paulo até o Rio Grande do Sul, na Mata Atlântica (Garcia \& Fernandes 2012). Floresce em setembro e frutifica nos últimos meses do ano.

\subsection{Leucaena leucocephala (Lam.) de Wit, Taxon} 10: 54. 1961.

Árvore ca. $4 \mathrm{~m}$ alt., ramo cilíndrico, glabro, inerme. Estípula ca. $3 \mathrm{~mm}$ compr., lanceolada, glabra, caduca; pecíolo 3,5-4 cm compr.; raque 6-8,5 cm compr., não alada; nectário foliar no pecíolo e entre os folíolos do par proximal. Folha bipinada, 12-14-foliolada; foliólulos ca. $3 \times 1,2$ $\mathrm{cm}$, estreitamente oblongos, base oblíqua, ápice agudo, margem inteira, ambas as faces glabras. Inflorescência em glomérulo esferóide, axilar. Cálice verde, gamossépalo, 5-laciniado, lacínios ca. 0,8 mm compr., piloso externamente. Corola alva, pétalas ca. 2,3 mm compr. Estames 10, livres, isodinamos, monocolores (alvos), ca. $10 \mathrm{~mm}$ compr., estaminódio ausente. Ovário ca. $2 \mathrm{~mm}$ compr., pubescente, não estipitado; estilete ca. $11 \mathrm{~mm}$ compr., glabro. Legume deiscente, 10-19 × 1-2 cm, glabro; 14-25 sementes, ca. $8 \times 4 \mathrm{~mm}$, elipsóides, castanhas. 
Material examinado: 28.XI.2007, fl. e fr., C. Snak 40 (UNOP).

Leucaena leucocephala é popularmente conhecida como leucena. Caracteriza-se na área pela inflorescência em glomérulo esferoide e odor característico. A espécie é nativa da América Central e introduzida no Brasil (NAS 1979). Floresce de novembro a abril e frutifica no mês de novembro.

2.8. Mimosa flocculosa Burkart, Darwiniana 13: 386. 1964. Figs. 2d-f, 4g

Árvore 5-7 m alt., ramo cilíndrico, tomentoso, com tricomas ramificados, inerme. Estípula 7-11 $\mathrm{mm}$ compr., filiforme, tomentosa, persistente; pecíolo 1,8-2,5 cm compr.; raque nula; nectário foliar ausente. Folha bipinada, 2-foliolada; foliólulos 1,1-1,3 × 0,3-0,4 cm, estreitamente triangulares, base oblíqua, ápice acuminado, margem inteira, face adaxial e abaxial tomentosa, com tricomas estrelados. Inflorescência em glomérulo esferoide, axilar. Cálice acinzentado, gamossépalo, 4-laciniado, lacínios ca. 0,8 $\mathrm{mm}$ compr., tomentoso externamente. Corola acinzentada, pétalas ca. $3 \mathrm{~mm}$ compr. Estames 4, monadelfos, monocolores (róseos), ca. $7 \mathrm{~mm}$ compr., estaminódios ausentes. Ovário ca. 0,7 mm compr., glabro, não estipitado; estilete ca. $6 \mathrm{~mm}$ compr., pubescente. Craspédio, 1-1,5 × 0,5-0,6 $\mathrm{cm}$, tomentoso, com tricomas ramificados; $2-4$ sementes, ca. $4 \times 1,5 \mathrm{~mm}$, oblongas, castanhas.

Material examinado: 29.III.2008, fl., C. Snak \& A. Snak 105 (UNOP); 17.V.2008, fr., C. Snak et al. 127 (UNOP); 28.VII.2008, fr., C. Snak \& A. Snak 176 (UNOP).

Mimosa flocculosa é popularmente conhecida como bracatinga-de-campo-mourão. Pode ser reconhecido na área de estudo pelos filetes rosados e pelo fruto craspédio. Ocorre de forma natural no Paraguai e no Brasil, onde está restrita ao Paraná na Floresta Estacional Semidecidual e Floresta Ombrófila Mista (Carvalho 2003; Dutra \& Morim 2012). A floração ocorre em março e a frutificação de maio a julho.

\subsection{Parapiptadenia rigida (Benth.) Brenan, Kew} Bull. 17(2): 228. 1963. Fig. 2g-h, $4 \mathrm{~h}$

Árvore 4-10 m alt., ramo levemente anguloso, glabro, inerme. Estípula 2-3 mm compr., lanceolada, tomentosa, caduca; pecíolo 1,8-4 cm compr.; raque 4,5-8 cm compr., não alada; nectário foliar no pecíolo, discóide. Folha bipinada, 12-14-foliolada; foliólulos $0,7-1 \times 0,1-0,3 \mathrm{~cm}$, estreitamente oblongos, base oblíqua, ápice cuspidado, margem inteira, face adaxial glabra, abaxial serícea.
Inflorescência em espiga, axilar. Cálice amareloesverdeado, gamossépalo, 5-laciniado, lacínios ca. 0,8 mm compr., tomentoso externamente. Corola amarelo-esverdeada, pétalas ca. $2 \mathrm{~mm}$ compr. Estames 10, livres, isodínamos, monocolores (creme), ca. $3 \mathrm{~mm}$ compr., estaminódio ausente. Ovário ca. $5 \mathrm{~mm}$ compr., glabro, estípite ca. $1 \mathrm{~mm}$ compr.; estilete 1,5 mm compr., glabro. Legume deiscente, $8-12 \times 0,8-1,5 \mathrm{~cm}$, glabro; 10-14 sementes, 5-7 × 5-6 mm, obladas, castanhas.

Material examinado: 19.X.2007, fl., C. Snak \& Q.C. Bortoli 31 (UNOP); 28.XI.2007, fl., C. Snak 38 (UNOP); 25.II.2008, fr., C. Snak \& A. Snak 90 (UNOP); 17.V.2008, fr., C. Snak et al. 123 (UNOP); 17.V.2008, fr., C. Snak et al. 130 (UNOP).

Parapiptadenia rigida é popularmente conhecida como angico-vermelho. Difere das demais espécies na área por apresentar folhas bipinadas e inflorescência em espiga. Ocorre de forma natural de São Paulo até o Rio Grande do Sul, na Mata Atlântica (Tamashiro 1989). Floresce de agosto a março e frutifica de fevereiro a maio.

2.10. Senegalia recurva (Benth.) Seigler \& Ebinger, Phytologia 88(1): 66. $2006 . \quad$ Figs. 2i, 4i

Arbusto decumbente ca. 2,5 m alt., ramo levemente anguloso, pubérulo, aculeado. Estípula ca. $5 \mathrm{~mm}$ compr., lanceolada, pubérula, persistente; pecíolo 2,5-3,5 cm compr.; raque 9-12 cm compr., não alada; nectário foliar no pecíolo e entre os foliolos do par distal, discóide. Folha, 32-38 foliolada; foliólulos ca. $6 \times 1 \mathrm{~cm}$, estreitamente elípticos, base oblíqua, ápice acuminado, margem inteira, ambas as faces glabras. Inflorescência em glomérulo esferóide, axilar ou terminal. Cálice creme, gamossépalo, 5-laciniado, lacínios ca. 1,2 mm compr., pubescentes externamente. Corola creme, pétalas ca. $2 \mathrm{~mm}$ compr. Estames numerosos, livres, isodínamos, monocolores (alvos), ca. 2,5 mm compr., estaminódio ausente. Ovário ca. 0,5 mm compr., viloso, estípite ca. $1 \mathrm{~mm}$ compr.; estilete ca. $1 \mathrm{~mm}$ compr., glabro. Legume deiscente, ca. $10 \times 2 \mathrm{~cm}$, glabro; 10-12 sementes, ca. $10 \times 5 \mathrm{~mm}$, ovadas, castanhas.

Material examinado: 12.XII.2007, fl., C. Snak 60 (UNOP); 25.II.2008, fr., C. Snak \& A. Snak 93 (UNOP).

Senegalia recurva é popularmente conhecida como nhapindá ou unha-de-gato. Pode ser reconhecida na área pelo hábito decumbente e presença de acúleos nos ramos. Ocorre naturalmente na Argentina, sul do Brasil e Paraguai (Burkart 1979; Rico-Arce 2007). A floração ocorre de dezembro a fevereiro e frutificação em fevereiro. 


\section{Papilionoideae}

3.1. Dalbergia nigra (Vell.) Benth., J. Linn. Soc., Bot. 4(Suppl.): 36. 1860.

Fig. 3a

Árvore ca. $3 \mathrm{~m}$ alt., ramo cilíndrico, glabro, inerme. Estípula ca. $1 \mathrm{~mm}$ compr., lanceolada, glabra, caduca; pecíolo 0,8-1,5 cm compr.; raque 4,5-9 cm compr.; nectário foliar ausente. Folha imparipinada, 17-23-foliolada; folíolos ca. 1,2 × 0,5-0,6 cm, oblongos, base obtusa, ápice retuso, margem inteira, face adaxial esparsamente pilosa, abaxial serícea. Inflorescência paniculada, axilar. Cálice verde, gamossépalo, 5-laciniado, lacínios 4-6 mm compr., piloso externamente. Corola roxa, estandarte 6-8 $\mathrm{mm}$ compr., asas 4-6 mm compr., pétalas da quilha $4-5 \mathrm{~mm}$ compr. Estames 10, monadelfos, 5-6,5 mm compr., estaminódio ausente. Ovário 4-4,5 mm compr., piloso, estípite 1-1,2 mm compr.; estilete 0,9-1,4 mm compr., glabrescente. Sâmara com núcleo seminífero central, 5-7 $\times 1-1,2 \mathrm{~cm}$, glabra, indeiscente; 1-2 sementes, ca. $9 \times 5 \mathrm{~mm}$, reniformes, castanhas.

Material examinado: 22.IV.2008, fr., C. Snak \& A. Snak 113 (UNOP).

Material adicional examinado: SÃO PAULO: Itirapina, Horto Florestal, 12.XI.1992, fl., A.M.G.A. Tozzi (UEC 063561).

Dalbergia nigra é popularmente conhecida como jacarandá-caviúna. Os folíolos oblongos de ápice retuso e a sâmara com núcleo seminífero central caracterizam a espécie. A espécie foi introduzida na área e ocorre de forma natural do sul da Bahia até o norte de São Paulo, na Floresta Atlântica (Carvalho 1997). Floresce de janeiro a março e frutifica em abril.

\subsection{Desmodium Desv.}

Erva, subarbusto ou arbusto. Folha 1-3-foliolada; estípula persistente. Inflorescência pseudorracemosa ou paniculada, terminal ou axilar; cálice gamossépalo, campanulado; corola dialipétala, papilionácea, rósea ou violácea; estames 10 , diadelfos (9+1); ovário séssil ou estipitado. Fruto lomento, 1-8-articulado, artículo indeiscente ou deiscente; sementes oblongas, obovadas ou reniformes.

3.2.1. Desmodium adscendens (Sw.) DC., Prodr. 2: 332.1825 .

Figs. 3b, $4 \mathrm{j}$

Subarbusto prostrado, ramo cilíndrico, pubescente, inerme. Estípula 3-4 $\mathrm{mm}$ compr., lanceolada, persistente; pecíolo 0,3-0,6 cm compr.; raque $0,2-0,4 \mathrm{~cm}$ compr.; nectário foliar ausente. Folha imparipinada, 3-foliolada; folíolo terminal $1-1,3 \times 0,9-1 \mathrm{~cm}$, folíolos laterais $0,7-1,1 \times 0,6-0,9$ $\mathrm{cm}$, obovados, base aguda, ápice retuso, margem inteira, ambas as faces pubescentes. Inflorescência pseudorracemosa, terminal. Cálice verde, 3-4 mm compr., pubescente externamente. Corola lilás, estandarte ca. $7 \mathrm{~mm}$ compr., asas ca. $6 \mathrm{~mm}$ compr., pétalas da quilha ca. $5 \mathrm{~mm}$ compr. Estames 10, diadelfos, ca. $4 \mathrm{~mm}$ compr., estaminódio ausente. Ovário ca. 3 mm compr., pubescente, não estipitado; estilete ca. $2 \mathrm{~mm}$ compr., glabro. Lomento, 1,5-2 $\times$ 0,4-0,6 cm, hirsuto-uncinado, artículo indeiscente, 3-4 articulado; 3-4 sementes, 3-4 × 2-3 mm, reniformes, castanhas.

Material examinado: 29.III.2008, fl. e fr., C. Snak \& A. Snak 108 (UNOP).

Material adicional examinado: PARANÁ: Tibagi, 21.I.2007, fl. e fr., A.L.P. Andrade 61 (UPCB).

Desmodium adscendens é popularmente conhecida como pega-pega. Caracteriza-se pelo hábito prostrado, fruto do tipo lomento, inflorescência pseudorracemosa e folíolos obovados. A espécie é de ampla distribuição, sendo encontrada em praticamente todo o Brasil, na Amazônia, Caatinga, Cerrado, Mata Atlântica e Pampa (Lima et al. 2012b). Floresce e frutifica principalmente de dezembro a abril.

3.2.2. Desmodium affine Schltdl., Linnaea 12: 312-313. 1838.

Fig. 3c

Subarbusto, ramo cilíndrico, pubescente, inerme. Estípula 3-6 mm compr., lanceolada, pilosa, persistente; pecíolo 1,9-2,5 $\mathrm{cm}$ compr.; raque 0,6-0,8 cm compr.; nectário foliar ausente. Folha imparipinada, 3-foliolada; folíolo terminal 2,5-3,4 $\times 1,7-2,1 \mathrm{~cm}$, folíolos laterias 2,4-2,8 × 1,1-1,5 cm, ovados, base obtusa, ápice arredondado a agudo, ou retuso, margem inteira, face adaxial estrigosa, abaxial esparsamente serícea. Inflorescência pseudorracemosa, terminal. Cálice ca. $4 \mathrm{~mm}$ compr., verde, pubescente externamente. Corola rosa, estandarte ca. $9 \mathrm{~mm}$ compr., asas ca. $7 \mathrm{~mm}$ compr., pétalas da quilha ca. $5 \mathrm{~mm}$ compr. Estames 10, diadelfos, ca. $5 \mathrm{~mm}$ compr., estaminódio ausente. Ovário ca. $4 \mathrm{~mm}$ compr., viloso, não estipitado; estilete ca. $3 \mathrm{~mm}$ compr., glabro. Lomento, $2-4 \times$ $0,3-0,5 \mathrm{~cm}$, hirsuto-uncinado, artículo indeiscente, 3-7 articulado; 3-7 sementes, 1,2-1,4 ×2,1-2,3 mm, reniformes, castanhas.

Material examinado: 29.III.2008, fl. e fr., C. Snak \& A. Snak 109 (UNOP).

Material adicional examinado: PARANÁ: São Jerônimo da Terra, 30.XI.1992, fl. e fr., J.M. Rodrigues (UPCB 25038).

Desmodium affine é popularmente conhecida como carrapicho, pega-pega. Caracteriza-se pelo hábito ereto, fruto do tipo lomento, inflorescência pseudorracemosa e folíolos ovados. O tipo de hábito, 


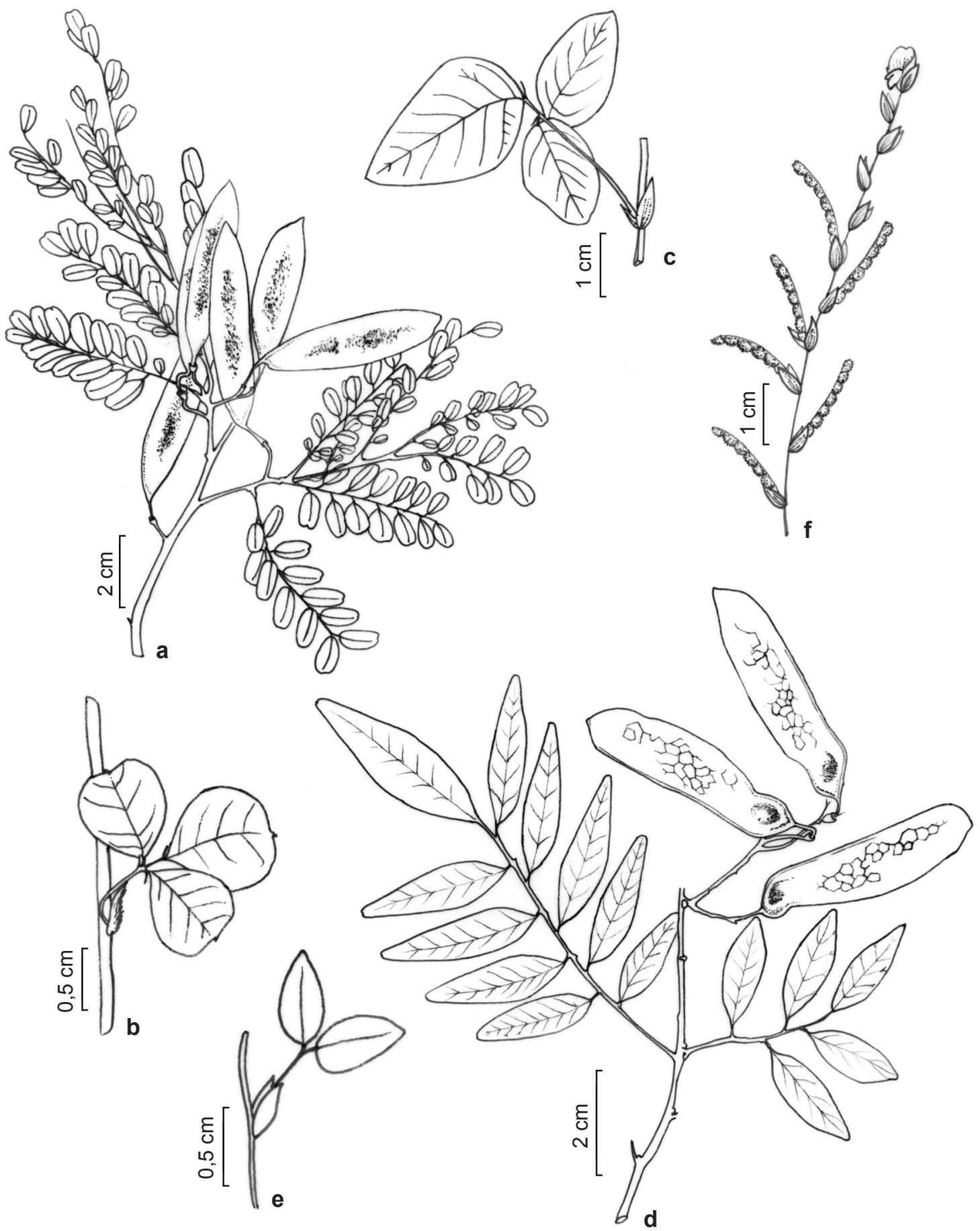

Figura 3 - a-f. Papilionoideae - a. Dalbergia nigra - ramo com frutos (C. Snak 113). b. Desmodium adscendens fragmento de ramo com folha (C. Snak 108). c. Desmodium affine - fragmento de ramo com folha (C. Snak 109). d. Machaerium stipitatum - ramo com frutos (C. Snak 111). e-f. Zornia curvata - e. fragmento de ramo com; f. folha ramo com brácteas e flor (C. Snak 107).

Figure 3 - a-f. Papilionoideae - a. Dalbergia nigra - branch with fruist (C. Snak 113). b. Desmodium adscendens - branch with leavel (C. Snak 108). c. Desmodium affine - branch with leavel (C. Snak 109). d. Machaerium stipitatum - branch with fruits (C. Snak 111). e-f. Zornia curvata - e. branch with leavel; f. branch with bracts and flower (C. Snak 107). 
a forma e o tamanho do folíolo, além do tipo de indumento do folíolo são características importantes para separar $D$. affine de $D$. adscendens. É uma espécie de ampla distribuição, sendo encontrada em praticamente todo o Brasil, na Amazônia, Cerrado, Mata Atlântica, Pampa e Pantanal (Lima et al. 2012b). Floresce e frutifica de novembro a abril.

3.3. Erythrina speciosa Andrews, Bot. Repos. 7: pl. 443.1806.

Fig. 4k

Arbusto ou arvoreta ca. $3 \mathrm{~m}$ alt., ramo cilíndrico, esparsamente piloso, aculeado. Estípula 10-12 mm compr., falcada, pilosa, caduca; pecíolo 9-11 cm compr.; raque 4,2-5 cm compr.; nectário foliar ausente. Folha imparipinada, 3-foliolada; folíolos 12-14 × 8,5-14,5 cm, largamente trulados, base obtusa, ápice agudo, margem inteira, face adaxial esparsamente pilosa, abaxial pubescente. Inflorescência racemosa, terminal. Cálice vináceo, gamossépalo, ca. $10 \mathrm{~mm}$ compr., pubescente externamente. Corola vermelha, estandarte ca. $70 \mathrm{~mm}$ compr., asas ca. $6 \mathrm{~mm}$ compr., pétalas da quilha ca. $30 \mathrm{~mm}$ compr. Estames 10, diadelfos, ca. $50 \mathrm{~mm}$ compr., estaminódio ausente. Ovário $20 \mathrm{~mm}$ compr., glabro estípite ca. $7 \mathrm{~mm}$ compr.; estilete ca. $18 \mathrm{~mm}$ compr., glabro. Legume deiscente, 16-31 $\times 0,7-1,5 \mathrm{~cm}$, glabro; $3-11$ sementes, $14-16 \times 7-8$ $\mathrm{mm}$, reniformes, castanhas.

Material examinado: 28.VII.2008, fl., C. Snak \& A. Snak 171 (UNOP).

Erythrina speciosa é popularmente conhecida como eritrina ou mulungú do litoral. Caracteriza-se pela presença de acúleos no tronco e flores vermelhas. Distribui-se pela América do Sul (Krukoff 1939). No Brasil é encontrada da Bahia até Santa Catarina, no Cerrado e Mata Atlântica (Lima 2012). Floresce duas vezes ao ano, novembro e dezembo, junho e julho e frutifica de outubro a novembro.

3.4. Holocalyx balansae Micheli, Mém. Soc. Phys. Genève 28(7): 41. 1883.

Fig. 41

Árvore ca. $4 \mathrm{~m}$ alt., ramo cilíndrico, pubérulo, inerme. Estípula 3-4 mm compr., linear, glabra, caduca; pecíolo $0,5-0,7 \mathrm{~cm}$ compr.; raque $12-$ $15 \mathrm{~cm}$ compr.; nectário foliar ausente. Folha paripinada, 48-54-foliolada; folíolos ca. 1,5-2 × $0,4 \mathrm{~cm}$, estreitamente elípticos, base oblíqua, ápice acuminado, margem serreada, ambas as faces glabras. Inflorescência racemosa, axilar. Cálice verde, gamossépalo, ca. $3 \mathrm{~mm}$ compr., pubérulo externamente. Corola verde, pétalas ca. $3 \mathrm{~mm}$ compr. Estames 14, livres, heterodínamos, 5-6 mm compr., estaminódio ausente. Ovário ca. $2 \mathrm{~mm}$ compr., pubérulo, estípite ca. $2 \mathrm{~mm}$ compr.; estilete ca. $1 \mathrm{~mm}$ compr., glabro. Drupa, 1,5-2 × 1,3-1,9 cm, glabro; 1 semente, ca. $10 \times 10 \mathrm{~mm}$, esférica, castanha.

Material examinado: 28.VII.2008, fl., C. Snak \& L.P. Poli 189 (UNOP).

Material adicional examinado: PARANÁ: Marechal Cândido Rondon, 20.VII.1967, fr., G. Hatschbach \& H. Haas 16600 (UPCB).

Holocalyx balansae é popularmente conhecida como alecrim-de-campinas. Pode ser facilmente reconhecida por apresentar folíolos serreados. Ocorre de forma natural no noroeste da Argentina, leste do Paraguai e no Brasil da Bahia até o Rio Grande do Sul, na Caatinga, Cerrado e Mata Atlântica (Carvalho 2003; Mansano \& Barros 2012). Floresce de agosto a setembro e frutifica de outubro a fevereiro.

\subsection{Machaerium stipitatum (DC.) Vogel, Linnaea} 11: 189. 1837.

Fig. 3d

Árvore ca. $7 \mathrm{~m}$ alt., ramo cilíndrico, glabro, inerme. Estípula ca. $1 \mathrm{~mm}$ compr., lanceolada, glabra, caduca; pecíolo $1-1,8 \mathrm{~cm}$ compr.; raque 4,5-7 cm compr.; nectário foliar ausente. Folha imparipinada, 5-13-foliolada; folíolos 3-5 × 0,7-1,5 cm, lanceolados a elípticos, base aguda, ápice retuso, margem inteira, face adaxial glabra, abaxial glabrescente. Inflorescência paniculada, axilar ou terminal. Cálice verde, gamossépalo, 0,5-1,2 mm compr., pubescente externamente. Corola creme, estandarte 5-5,6 mm compr., asas 5-5,4 mm compr., pétalas de quilha 4-4,3 $\mathrm{mm}$ compr. Estames 10, monadelfos, ca. $4 \mathrm{~mm}$ compr., estaminódio ausente. Ovário 2-2,2 mm compr., piloso, estípite 1,5-1,7 mm compr.; estilete 1,2-1,4 mm compr., glabro. Sâmara com núcleo seminífero basal, 4-4,5 × 1-1,5 cm, glabra; 1 semente, ca. $9 \times$ $6 \mathrm{~mm}$, reniforme, castanha.

Material examinado: 22.IV.2008, fr., C. Snak \& $A$. Snak 111 (UNOP).

Material adicional examinado: PARANÁ: Londrina, Parque Estadual Mata dos Godoy, 20.II.1989, fl., L.H. Soares \& Silva 193 (UPCB).

Machaerium stipitatum é popularmente conhecida como sapuva. Caracteriza-se pelos folíolos lanceolados a elípticos de ápice retuso e fruto sâmara com o núcleo seminífero basal. Ocorre de forma natural no nordeste da Argentina e no leste do Paraguai. No Brasil, está presente desde a Bahia até o Rio Grande do Sul, no Cerrado e Mata Atlântica (Carvalho 2006; Filardi 2012). Floresce de dezembro a março e frutifica em abril. 

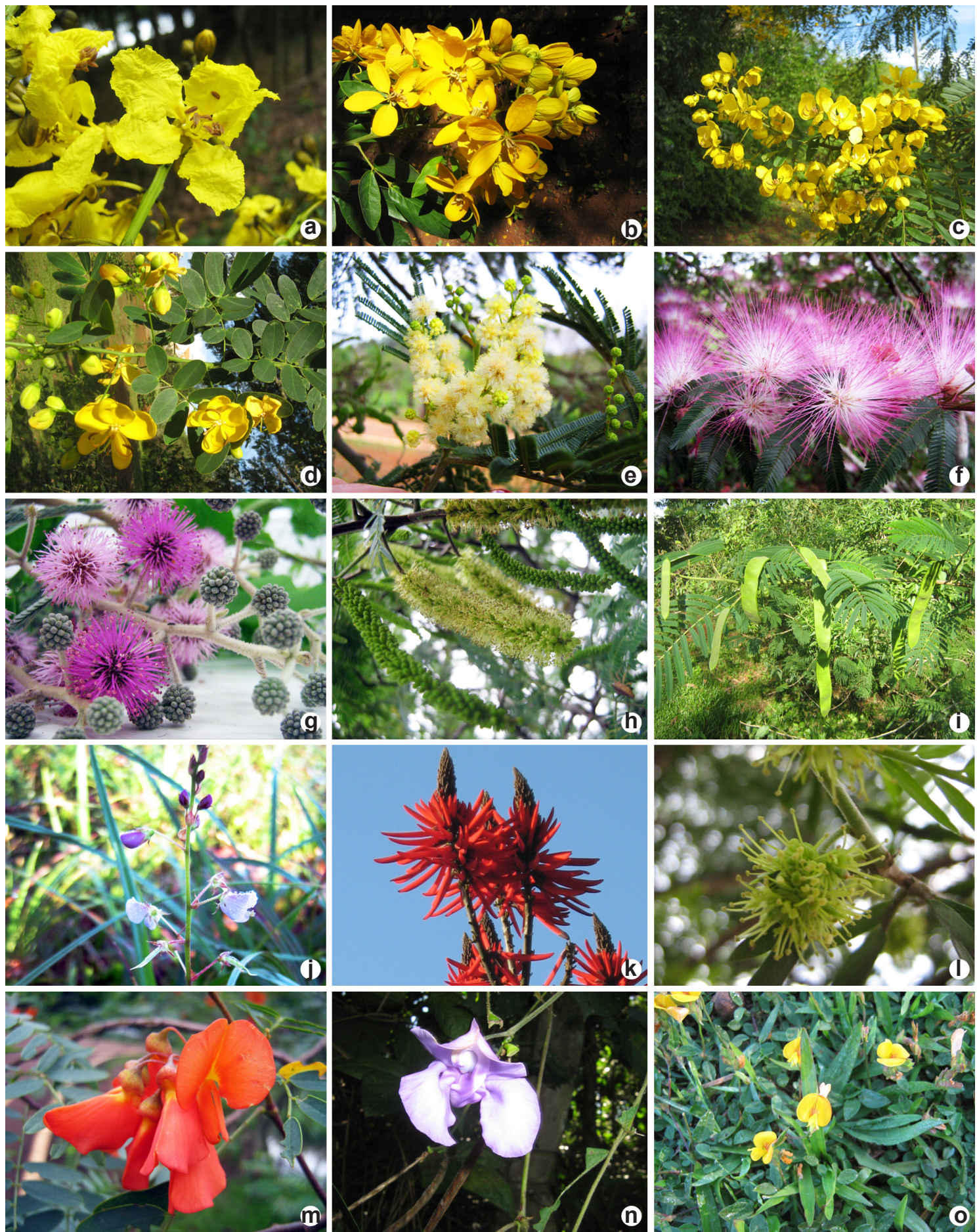

Figura 4 - Leguminosas com ocorrência no Parque Ecológico Paulo Gorski, Cascavel-PR. a. Schizolobium parahyba; b. Senna macranthera; c. S. multijuga; d. S. pendula; e. Acacia mearnsii; f. Calliandra brevipes; g. Mimosa flocculosa; h. Parapiptadenia rigida; i. Senegalia recurva; j. Desmodium adscendens; k. Erythrina speciosa; 1. Holocalix balansae; m. Sesbania punicea; n. Sigmoidotropis speciosa; o. Zornia curvata.

Figure 4 - Legumes with occurrence in Parque Ecológico Paulo Gorski, Cascavel-PR. a. Schizolobium parahyba; b. Senna macranthera; c. S. multijuga; d. S. pendula; e. Acacia mearnsii; f. Calliandra brevipes; g. Mimosa flocculosa; h. Parapiptadenia rigida; i. Senegalia recurva; j. Desmodium adscendens; k. Erythrina speciosa; 1 . Holocalix balansae; m. Sesbania punicea; n. Sigmoidotropis speciosa; 0 . Zornia curvata. 
3.6. Sesbania punicea (Cav.) Benth., Fl. bras. 15(1A): 43.1859.

Fig. $4 \mathrm{~m}$

Arbusto ca. $2 \mathrm{~m}$ alt., ramo estriado, glabro, inerme. Estípula ca. $4 \mathrm{~mm}$ compr., linear, pilosa, caduca; pecíolo 0,7-2,3 cm compr.; raque 6-9 cm compr.; nectário foliar ausente. Folha imparipinada, 11-23-foliolada; folíolos 1-1,7 × $0,3-0,5 \mathrm{~cm}$, oblanceolados, base arredondada, ápice mucronulado, margem inteira, ciliada, face adaxial glabra, abaxial esparsamente pilosa. Inflorescência racemosa, axilar. Cálice verde, gamossépalo, 5-laciniado, lacínios ca. $5 \mathrm{~mm}$ compr., glabro externamente. Corola vermelha ou alaranjada, estandarte ca. $15 \mathrm{~mm}$ compr., asas ca. $18 \mathrm{~mm}$ compr., pétalas da quilha ca. $20 \mathrm{~mm}$ compr. Estames 10, diadelfos, ca. $15 \mathrm{~mm}$ compr., estaminódio ausente. Ovário ca. $15 \mathrm{~mm}$ compr., glabro, estípite ca. $4 \mathrm{~mm}$ compr.; estilete ca. $0,5 \mathrm{~mm}$ compr., glabro. Legume deiscente alado, 5-9 $51-2 \mathrm{~cm}$, glabro; 3-8 sementes, ca. $10 \times 7 \mathrm{~mm}$, reniformes, castanhas.

Material examinado: 19.X.2007, fl. e fr., C. Snak \& Q.C. Bortoli 28 (UNOP); 25.II.2008, fl. e fr., C. Snak \& A. Snak 97 (UNOP).

Sesbania punicea é popularmente conhecida como sesbania. Pode ser facilmente reconhecida na área por apresentar legume alado. A espécie nativa da Argentina, Uruguai e no Brasil, onde está presente no Sul, Mato Grosso do Sul, São Paulo e Rio de Janeiro, n Mata Atlântica, Pampa e Pantanal (Hoffmann \& Moran 1998; Iganci \& Miotto 2012). Floresce de setembro a março e frutifica de fevereiro a abril.

3.7. Sigmoidotropis speciosa (Kunth) A. Delgado, Amer. J. Bot. 98 (10): 1711. $2011 . \quad$ Fig. 4n

Erva volúvel, ramo estriado, piloso, inerme. Estípula 3-4 mm compr., lanceolada, ciliada, persistente; pecíolo 5-8 cm compr.; raque ca. 1,5 cm compr.; nectário foliar ausente. Folha imparipinada, 3-foliolada; folíolo 7-10 × 4-5,4 cm, lanceolados, base obtusa, ápice cuspidado, margem inteira, face adaxial estrigosa, abaxial esparso serícea. Inflorescência pseudorracemosa, axilar. Cálice verde, gamossépalo, 4-laciniado, lacínios ca. $7 \mathrm{~mm}$ compr., glabro externamente. Corola violácea, estandarte ca. $25 \mathrm{~mm}$ compr., asas ca. 27 $\mathrm{mm}$ compr., pétalas de quilha ca. $20 \mathrm{~mm}$ compr, torcidas lateralmente. Estames 10, diadelfos, ca. $20 \mathrm{~mm}$ compr., estaminódio ausente. Ovário ca. $7 \mathrm{~mm}$ compr., tomentoso, estípite ca. $1 \mathrm{~mm}$ compr.; estilete ca. $18 \mathrm{~mm}$ compr., glabrescente. Legume deiscente, ca. 7,5-10 × 0,5 cm, seríceo; 7-13 sementes, ca. 3 $\times 1 \mathrm{~mm}$, oblongas, castanhas.
Material examinado: 29.III.2008, fl. e fr., C. Snak \& A. Snak 99 (UNOP). 16.I.2010, fl. e fr., C. Snak \& A. Snak 296 (UPCB).

Sigmoidotropis speciosa é popularmente conhecida como feijão-do-mato e foi segregada do gênero Vigna Savi recentemente por DelgadoSalinas et al. (2011). Caracteriza-se pela corola violácea e pétalas da quilha torcidas lateralmente. A espécie tem ampla distribuição geográfica, sendo encontrada da América Central ao norte da Argentina (Maréchal et al. 1978). No Brasil ocorre do Mato Grosso até o Paraná, em Cerrado e Mata Atlântica (Perez 2012). Floresce e frutifica durante os primeiros meses do ano.

3.8. Tipuana tipu (Benth.) Kuntze, Revis. Gen. Pl. 3(3): 72.1898.

Árvore ca. $7 \mathrm{~m}$ alt., ramo cilíndrico, pubescente, inerme. Estípula não observada, caduca; pecíolo 1,5$3 \mathrm{~cm}$ compr.; raque 9,5-15 cm compr.; nectário foliar ausente. Folha imparipinada, 9-15-foliolada; folíolos 3-4,5 × 1,5-1,8 cm, oblongos, base oblíqua, ápice retuso, margem inteira, face adaxial glabra, abaxial pilosa. Inflorescência racemosa ou paniculada, axilar ou terminal. Cálice verde, gamossépalo, 5-laciniado, lacínios 5-7 mm compr., pubescente externamente. Corola amarela, estandarte 10-15 $\mathrm{mm}$ compr., asas 13-15 mm compr., pétalas da quilha 8-10 mm compr. Estames 10, diadelfos, 6-8 $\mathrm{mm}$ compr., estaminódio ausente. Ovário 7-8 mm compr., tomentoso, não estipitado; estilete $2-3 \mathrm{~mm}$ compr., glabro. Sâmara com núcleo seminífero basal, ca. $6,5 \times 2,5 \mathrm{~cm}$, esparsamente pilosa; 1 semente, ca. $15 \times 15 \mathrm{~mm}$, esferoide, castanha.

Material examinado: 29.III.2008, fr., C. Snak \& A. Snak 100 (UNOP); 29.X.2008, fl., C. Snak 207 (UNOP).

Tipuana tipu é popularmente conhecida como tipuana. Distingue-se na área de estudo pelos folíolos oblongos de ápice retuso, flores amarelas e fruto sâmara com núcleo seminífero basal. A espécie é nativa do sul da Bolívia e norte da Argentina (NAS 1979). Amplamente cultivada no Brasil como ornamental. Floresce em outubro, frutificando de fevereiro a maio.

3.9. Zornia curvata Mohlenbr., Webbia 16(1): 132-136, f. 62, 91. $1961 . \quad$ Fig. 3e-f, 4o

Subarbusto, ramo cilíndrico, glabro, inerme. Estípula ca. $3 \mathrm{~mm}$ compr., lanceolada, glabra, persistente; pecíolo 0,5-1,1 cm compr.; raque nula; nectário foliar ausente. Folha paripinada, 2-foliolada; folíolo 0,8-1 × 0,4-0,5 cm, oblongos, base oblíqua, 
ápice agudo, margem inteira, ambas as faces glabras. Inflorescência racemosa, terminal. Cálice verde, gamossépalo, 5-laciniado, lacínios ca. 4 mm compr., pubescente externamente. Corola amarela, estandarte ca. $10 \mathrm{~mm}$ compr., asas ca. $7 \mathrm{~mm}$ compr., pétalas de quilha ca. $8 \mathrm{~mm}$ compr. Estames 10, monadelfos, ca. $7 \mathrm{~mm}$ compr., estaminódio ausente. Ovário ca. 2 $\mathrm{mm}$ compr., pubescente, não estipitado; estilete ca. 6 $\mathrm{mm}$ compr., glabro. Lomento, ca. 0,6-1,7 $\times 0,1 \mathrm{~cm}$, híspido; 5-7 sementes, ca. $1 \times 1 \mathrm{~mm}$, ovadas, verdes. Material examinado: 29.III.2008, fl. e fr., C. Snak \& A. Snak 107 (UNOP).

Zornia curvata é popularmente conhecida como zornia. Pode ser reconhecida na área de estudo pelo hábito herbáceo, folhas bi-folioladas e fruto lomento. Ocorre naturalmente em toda a América de forma disjunta, no Brasil está presente desde a Paraíba até o Rio Grande do Sul, em campos limpos e graminosos, campos rupestres, com solos pedregosos e também em cerrados (GRIN 2008; Fortuna-Perez 2009). Floresce e frutifica de fevereiro a julho.

\section{Agradecimentos}

As autoras agradecem aos curadores e funcionários dos herbários visitados. À Secretaria Municipal do Meio Ambiente/Cascavel a concessão da licença de coleta. Ao PIBIC/UNIOESTE a bolsa de iniciação científica da primeira autora. À ONG Selva Paranaense o auxílio durante o projeto. À Dr ${ }^{\mathrm{a}}$ A.P. Fortuna-Perez pela ajuda com as identificações. À $\mathrm{Dr}^{\mathrm{a}}$ E. de Souza o auxílio com a terminologia morfológica em Mimosoideae e à T. Meurer as ilustrações.

\section{Referências}

Barroso, G.M.; Peixoto, A.L.; Costa, C.G.; Ichaso, C.L.F.; Guimarães, E.F. \& Lima, H.C. 1991. Sistemática das angiospermas do Brasil. Vol. 2. Ed. Universidade Federal de Viçosa, Viçosa. 326p.

Barroso, G.M.; Morim, M.P.; Peixoto, A.L. \& Ichaso, C.L.F. 1999. Frutos e sementes: morfologia aplicada à sistemática de dicotiledôneas. Ed. Universidade Federal de Viçosa, Viçosa. 443p.

Bortoluzzi, R.L.C.; Miotto, S.T.S. \& Reis, A. 2006. Leguminosas-Cesalpinioídeas - Tribos Cercideae e Detarieae: Bauhinia, Copaifera e Tamarindus. In: Reis, A. (ed.). Flora Ilustrada Catarinense. Herbário Barbosa Rodrigues, Itajaí. 96p .

Bridson, D. \& Forman, L. 2004. The herbarium handbook. The Royal Botanic Gardens, Kew. 346p.

Brummit, R.K. \& Powell, C.E. 1992. Authors of plants names. The Royal Botanic Gardens, Kew. 732p.
Bruneau, A.; Mercure, M.; Lewis, G.P. \& Herendeen, P.S. 2008. Phylogenetic patterns and diversification in the caesalpinioid legumes. Botany 86: 697-718.

Burkart, A. 1979. Leguminosas Mimosoideas. In: Reitz, P.R. (ed.). Flora Ilustrada Catarinense, part 1. Herbário Barbosa Rodrigues, Itajaí. 304p.

Carvalho, A.M. 1997. A Synopsis of the Genus Dalbergia (Fabaceae: Dalbergieae) in Brazil. Brittonia 49: 87-109.

Carvalho, P.E.R. 2003. Espécies arbóreas brasileiras. Vol. 1. Embrapa Florestas, Colombo. 1039p.

Carvalho, P.E.R. 2006. Espécies arbóreas brasileiras. Vol. 2. Embrapa Florestas, Colombo. 627p.

Delgado-Salinas, A.; Thulin, M.; Pasquet, R.; Weeden, N. \& Lavin, M. 2011. Vigna (Leguminosae) sensu lato: the names and identities of the American segregate genera. American Journal of Botany 98: 1694-1715.

Dutra, V.F. \& Morim, M.P. 2012. Mimosa. In: Forzza, R.C. et al. (eds.). Lista de espécies da flora do Brasil. Jardim Botânico do Rio de Janeiro. Disponível em $<$ http://floradobrasil.jbrj.gov.br/2012/FB031156>. Acesso em Mai 2012.

Filardi, F.L.R. 2012. Machaerium. In: Forzza, R.C. et al (eds.). Lista de espécies da flora do Brasil. Jardim Botânico do Rio de Janeiro. Disponível em <http:// floradobrasil.jbrj.gov.br/2012/FB029781>. Acesso em Mai 2012.

Fortuna-Perez, A.P. 2009. O gênero Zornia J. F. Gmel. (Leguminosae, Papilionoideae, Dalbergieae): revisão taxonomica das especies ocorrentes no Brasil e filogenia. Tese de Doutorado. Universidade Estadual de Campinas, Campinas. 285p.

FUNDETEC - Fundação para o desenvolvimento científico e tecnológico. 1995. Bacia Hidrográfica do Rio Cascavel - Proposta para recuperação ambiental. FUNDETEC, Cascavel. 164p.

Garcia, F.C.P. \& Fernandes, J.M. 2012. Inga. In: Forzza, R.C. et al. (eds.). Lista de espécies da flora do Brasil. Jardim Botânico do Rio de Janeiro. Disponível em $<$ http://floradobrasil.jbrj.gov.br/2012/FB023041>. Acesso em Mai 2012.

GRIN - Germplasm Resources Information Network [Online Database]. National Germplasm Resources Laboratory, Beltsville, Maryland. Disponível em $<$ http://www.ars-grin.gov/cgi-bin/npgs/html/taxon. pl?424957>. Acesso em 10 Out 2008.

Hoffmann, J.H. \& V.C. Moran. 1998. The population dynamics of an introduced tree, Sesbania punicea, in South Africa, in response to long-term damage caused by different combinations of three species of biological control agents. Oecologia 114: 343-348.

IAPAR. 2000. Cartas climáticas do Paraná. Disponível em $<$ http://www.iapar.br/modules/conteudo/conteudo. php? conteudo=863>. Acesso em 10 Mai 2012.

IBGE - Instituto Brasileiro de Geografia e Estatística. 1992. Manual técnico da vegetação brasileira. IBGE, Rio de Janeiro. 91p. 
Iganci, J.R.V. 2012. Albizia. In: Forzza, R.C. et al. (eds.). Lista de espécies da flora do Brasil. Jardim Botânico do Rio de Janeiro. Disponível em <http:// floradobrasil.jbrj.gov.br/2012/FB082616>. Acesso em Mai 2012.

Iganci, J.R.V. \& Miotto, S.T.S. 2012. Sesbania. In: Forzza, R.C. et al. (eds.). Lista de espécies da flora do Brasil. Jardim Botânico do Rio de Janeiro. Disponível em $<$ http://floradobrasil.jbrj.gov.br/2012/FB101171>. Acesso em Mai 2012.

Irwin, H.S. \& Barneby, R.C. 1982. The American Cassiinae - A synoptical revision of Leguminosae Tribe Cassieae subtribe Cassiinae in the New World. Memoirs of the New York Botanical Garden 35: 1-918.

Kirkbride-Jr, J.H.; Gunn, C.R. \& Weitzman, A.L. 2003. Fruits and seeds of genera in the subfamily Faboideae (Fabaceae). Vol. 1. USDA Technical Bulletin, Washington. 77p.

Krukoff, A. 1939. The American species of Erythrina. Brittonia 3: 205-337.

Lewis, G.P. 1987. Legumes of Bahia. Royal Botanic Gardens, Kew. 369p.

Lewis, G.P. 2012a. Libidibia. In: Forzza, R.C. et al. (eds.). Lista de espécies da flora do Brasil. Jardim Botânico do Rio de Janeiro. Disponível em <http:// floradobrasil.jbrj.gov.br/2012/FB109828>. Acesso em Mai 2012.

Lewis, G.P. 2012b. Peltophorum. In: Forzza, R.C. et al. (eds.). Lista de espécies da flora do Brasil. Jardim Botânico do Rio de Janeiro. Dispinível em $<$ http:// floradobrasil.jbrj.gov.br/2012/FB083567>. Acesso em Mai 2012.

Lewis, G.P. 2012c. Poincianella. In: Forzza, R.C. et al. (eds.). Lista de espécies da flora do Brasil. Jardim Botânico do Rio de Janeiro. Disponível em <http:// floradobrasil.jbrj.gov.br/2012/FB109778>. Acesso em Mai 2012.

Lewis, G.P. 2012d. Schizolobium. In: Forzza, R.C. et al. (eds.). Lista de espécies da flora do Brasil. Jardim Botânico do Rio de Janeiro. Disponível em $<$ http:// floradobrasil.jbrj.gov.br/2012/FB023143>. Acesso em Mai 2012.

Lewis, G.P. \& Gibbs, P.E. 1999. Reproductive biology of Caesalpinia calycina and C. pluviosa (Leguminosae) of the caatinga of north-eastern Brazil. Plant Systematics and Evolution 217: 43-53.

Lewis, G.; Schrire, B.; Mackinder, B. \& Lock, M. 2005. Legumes of the world. Royal Botanic Gardens, Kew. 577p.

Lima, H.C.; Tozzi; A.M.G.A.; Fortuna-Perez, A.P.; Flores, A.S.; Vaz, A.M.S.F.; Klitgaard, B.B.; Cardoso, D.B.S; Filardi, F.R.; Garcia, F.C.; Lewis, G.P.; Iganci, J.R.V.; Meireles, J. E.; Valls, J.F.M.; Lima, L.C.P.; Queiroz, L.P.; Silva, M.J.; Morin, M.P.; Barros, M.J.F.; Queiroz, R.T.; Fortunato, R.H.; Pennigton, R.T.; Miotto, S.T.; Moura, T.M.; Dutra, F.D.; Mansano, V.F.; Souza, V.C. \& Scalon, V.R. 2009. Fabaceae.
In: Stehmann, J.R.; Forzza, R.C.; Salino, A.; Sobral, M.; Costa, D.P. \& Kamino, L.H.Y. (eds.). Plantas da Floresta Atlântica. Jardim Botanico do Rio de Janeiro, Rio de Janeiro. 505p.

Lima, H.C. 2012. Erythrina. In: Forzza, R.C. et al. (eds.). Lista de espécies da flora do Brasil. Jardim Botânico do Rio de Janeiro. Disponível em $<$ http:// floradobrasil.jbrj.gov.br/2012/FB029677>. Acesso em Mai 2012.

Lima, H.C.; Queiroz, L.P.; Morim, M.P.; Souza, V.C.; Dutra, V.F.; Bortoluzzi, R.L.C.; Iganci, J.R.V.; Fortunato, R.H.; Vaz, A.M.S.F.; Souza, E.R.; Filardi, F.L.R.; Valls, J.F.M.; Garcia, F.C.P.; Fernandes, J.M.; Martins-da-Silva, R.C.V.; Perez, A.P.F.; Mansano, V.F.; Miotto, S.T.S.; Tozzi, A.M.G.A.; Meireles, J.E.; Lima, L.C.P.; Oliveira, M.L.A.A.; Flores, A.S.; Torke, B.M.; Pinto, R.B.; Lewis, G.P.; Barros, M.J.F.; Schütz, R.; Pennington, T.; Klitgaard, B.B.; Rando, J.G.; Scalon, V.R.; Cardoso, D.B.O.S.; Costa, L.C.; Silva, M.J.; Moura, T.M.; Barros, L.A.V.; Silva, M.C.R.; Queiroz, R.T.; Sartori, A.L.B. \& Camargo, R. 2012a. Fabaceae. In: Forzza, R.C. et al. (eds.). Lista de espécies da flora do Brasil. Jardim Botânico do Rio de Janeiro. Disponível em $<$ http:// floradobrasil.jbrj.gov.br/2012/FB000115>. Acesso em Mai 2012.

Lima, L.C.P.; Oliveira, M.L.A.A. \& Tozzi, A.M.G.A. 2012b. Desmodium. In: Forzza, R.C.et al. (eds.). Lista de espécies da flora do Brasil. Jardim Botânico do Rio de Janeiro. Disponível em $<$ http://floradobrasil. jbrj.gov.br/2012/FB022931>. Acesso em Mai 2012.

Mansano, V.F. \& Barros, L.A.V. 2012. Holocalyx. In: Forzza, R.C. et al. (eds.). Lista de espécies da flora do Brasil. Jardim Botânico do Rio de Janeiro. Disponível em < http://floradobrasil.jbrj.gov.br/2012/FB031005>. Acesso em Mai 2012.

Maréchal, R.; Mascherpa, J.M. \& Stainer, F. 1978. Étude taxonomique d'un groupe complex d'espéces des genres Phaseolus et Vigna (Papilionaceae) sur la base de données morphologiques et polliniques, traitées par l'analyse informatique. Boissiera 28: 1- 273.

Morim, M.P. 2012a. Anadenanthera. In: Forzza, R.C. et al. (eds.). Lista de espécies da flora do Brasil. Jardim Botânico do Rio de Janeiro. Disponível em: <http:// floradobrasil.jbrj.gov.br/2012/FB018071>. Acesso em Mai 2012.

Morim, M.P. 2012b. Enterolobium. In: Forzza, R.C. et al. (eds.). Lista de espécies da flora do Brasil. Jardim Botânico do Rio de Janeiro. Disponível em: <http:// floradobrasil.jbrj.gov.br/2012/FB083154>. Acesso em Mai 2012.

NAS - National Academy Of Sciences. 1979. Tropical legumes: resources for the future. National Academy of Sciences and the National Research Council, Washington. 187p.

Perez, A.P.F. 2012. Vigna. In: Forzza, R.C. et al. (eds.). Lista de espécies da flora do Brasil. Jardim 
Botânico do Rio de Janeiro. Disponível em <http:// floradobrasil.jbrj.gov.br/2012/FB029913>. Acesso em Mai 2012.

Polhill, R.M. \& Raven, P.H. 1981. Advances in legume systematics part I. Royal Botanic Gardens, Kew. 425p.

Queiroz, L.P. de. 2009. Leguminosas da caatinga. Universidade Estadual de Feira de Santana. Feira de Santana. $467 \mathrm{p}$.

Radford, A.E.; Dickison, W.C.; Massey, J.R. \& Bell, C.R. 1974. Vascular plant systematics. Harper \& Row, New York. 891p.

Roderjan, C.V.; Galvão, F.; Kuniyoshi, Y.S. \& Hatschbach, G.G. 2002. As unidades fitogeográficas do estado do Paraná. Ciência \& Ambiente 24: 75-92.

Rico-Arce, M.L. 1992. Notes on Albizia niopoides (Spruce ex Benth.) Burkart (Leguminosae: Mimosoideae). Kew Bull. 47: 699-702.

Rico-Arce, M.L. 2007. A Checklist and synopsis of american species of Acacia (Leguminosae: Mimosoideae). Conabio, Mexico City. 207p.

Roskov Y.R.; Bisby F.A.; Zarucchi J.L.; Schrire B.D. \& White R.J. 2005. ILDIS World Database of Legumes: draft checklist, version 10. ILDIS, United Kingdom. CD-ROM.

Souza, E.R. de 2012. Calliandra. In: Forzza, R.C. et al. (eds.). Lista de espécies da flora do Brasil. Jardim Botânico do Rio de Janeiro. Disponível em $<$ http:// floradobrasil.jbrj.gov.br/2012/FB082710>. Acesso em Mai 2012.

Souza, V.C. \& Bortoluzzi, R.L.C. 2012a. Cassia. In: Forzza, R.C. et al. (eds.). Lista de espécies da flora do Brasil. Jardim Botânico do Rio de Janeiro. Disponível em: $<$ http://floradobrasil.jbrj.gov.br/2012/ FB100880>. Acesso em Mai 2012.

Souza, V.C. \& Bortoluzzi, R.L.C. 2012b. Senna. In: Forzza, R.C. et al. (eds.). Lista de espécies da flora do Brasil. Jardim Botânico do Rio de Janeiro. Disponível em < http://floradobrasil.jbrj.gov.br/2012/ FB028201>. Acesso em Mai 2012.

Tamashiro, J. Y. 1989. Estudos taxonômicos morfológicos do gênero Piptadenia, sensu Bentham no sudeste do Brasil. Avaliação das modificações taxonômicas recentemente propostas. Dissertação de Mestrado. Universidade Estadual de Campinas, Campinas. 99p.

Thiers, B. [continuously updated]. Index Herbariorum: a global directory of public herbaria and associated staff. New York Botanical Garden's Virtual Herbarium. Disponível em $<$ http://sweetgum.nybg. org/ih/>. Acesso em Mai 2012.

Veloso, H.P.; Rangel Filho, A.L.R. \& Lima, J.C.A. 1991. Classificação da vegetação brasileira, adaptada a um sistema universal. IBGE, Rio de Janeiro. 123p.

Wojciechowski, M.F. 2003. Reconstructing the phylogeny of legumes (Leguminosae): an early $21^{\text {st }}$ century perspective. In: Klitgaard, B.B. \& Bruneau, A. (eds.). Advances in legume systematics 10: higher level systematics. Royal Botanic Gardens, Kew. Pp. 5-35.

Wojciechowski, M.F.; Lavin, M. \& Sanderson, M.J. 2004. A phylogeny of legumes (Leguminosae) based on analysis of the plastid matK gene resolves many wellsupported subclades within the family. American Journal of Botany 91: 1846-1862.

\section{Lista de exsicatas}

Andrade, A.L.P.: 61 (3.2.1); Hatschbach, G.: 16600 (3.4); Kozera, C.: 522 (2.5); Rodrigues, J.M.: UPCB 25038 (3.2.2); Snak, C.: $39,114,115,136$ (1.1); 48, 173 (1.2.1); 126, 192 (1.2.2); 160, 213 (1.3); 61, 91 (1.4); 190, 210 (1.5); 77, 102 (1.6.1); 39, 186 (1.6.2); 104, 174 (1.6.3); 08, 110, 172 (2.1.1); 60, 93 (2.1.2); 112, 145, 208 (2.2); 92 (2.3); 201, 209 (2.4); 202 (2.5); 40 (2.6); 105, 127,176 (2.7); 31, 38, 90, 123, 130 (2.8); 113 (3.1); 108 (3.2.1); 109 (3.2.2); 171, 211 (3.3); 189 (3.4); 111 (3.5); 28,97 (3.6); 100,207 (3.7); 99, 296 (3.8); 107 (3.9); Soares, L.H.: 193 (3.5); Tozzi, A.M.G.A.: UEC 063561 (3.1). 
